\title{
Musculoskeletal disorders: OWAS review
}

\author{
Marta GÓMEZ-GALÁN ${ }^{1 *}$, José PÉREZ-ALONSO ${ }^{1}$, Ángel-Jesús CALLEJÓN-FERRE ${ }^{1,2}$ and \\ Javier LÓPEZ-MARTÍNEZ ${ }^{1}$
}

\author{
${ }^{1}$ Department of Engineering, University of Almería, Spain \\ ${ }^{2}$ Laboratory-Observatory Andalusian Working Conditions in the Agricultural Sector (LASA), Spain
}

Received November 3, 2016 and accepted May 2, 2017

Published online in J-STAGE May 9, 2017

\begin{abstract}
The prevention of musculoskeletal disorders (MSD) is very important in the world. Governments and companies are the most interested. The objective of the present work is to review the literature on the applications of the OWAS method in the diverse sectors or fields of knowledge and countries from its publication to March 2017. The use of OWAS method has been classified by categories of knowledge, by country and by year. The search was made by selecting only the main collection of the Web of Science. This was selected by the option "Advanced search" using the term OWAS (ts=OWAS) for the time period of 1900 to 2017. A total of 166 results were found, consisting of conference papers and articles in scientific journals. In conclusion, the OWAS has been applied mainly in two sectors: "Manufacturing industries" and "Healthcare and Social assistance activities". This method needs to be complemented with other indirect or direct methods. Also, whenever the OWAS has been used, whether individually or together with other methods, musculoskeletal disorders risks have been detected, this perhaps being an indicator to review the evaluation parameters because overestimating the risk.
\end{abstract}

Key words: Observation methods, OWAS, Posture evaluation, Ergonomics, Prevention

\section{Introduction}

\subsection{Definition and standards}

Musculoskeletal disorders (MSD) extend to almost all occupations and sectors, bearing critical physical and economic consequences for the sufferer: workers, families, businesses, and governments. These ailments are considered the most common labour medical problems among workers in the European Union. The continual exposure of workers to different labour risks leads to these disorders and despite their varied forms of appearance, they can be classified into two broad groups: accumulative (upper and lower limbs) and dorsolumbar injuries ${ }^{1-3)}$.

The Finnish Institute of Occupational Health (FIOH) identified musculoskeletal disorders as one of the most

*To whom correspondence should be addressed.

E-mail: marta.galan.92@gmail.com

(C)2017 National Institute of Occupational Safety and Health common work-related infirmity, emphasizing that despite numerous parts of the body being involved, the back accounts for most of the discomfort ${ }^{4}$.

According to the Occupational Safety \& Health Administration $^{5)}$ of the Department of Labour of the United States of America, musculoskeletal disorders cause great losses of work hours. Each year, a high number of American workers suffer work-related MSD in the back and shoulders, tendinitis, and carpal tunnel syndrome.

The Canadian Centre for Occupational Health and Safety ${ }^{6}$ affirms that MSD constitute a grave problem. Therefore, risk evaluation needs to be established to reduce risk, as these complaints cause many absences, heavy economic losses, and reductions in productivity.

The World Health Organization defines MSD as "health problems of the locomotor apparatus, i.e. muscles, tendons, bone skeleton, cartilage, ligaments, and nerves. This includes any type of complaint, from slight transitory discomforts to irreversible and incapacitating injuries"7). 
Table 1. Classification of the semidirect methods according to the cause of the MSD

\begin{tabular}{|c|c|c|}
\hline Repetitive Movements & Strained Postures & Handling of Loads \\
\hline RULA method $^{10)}$ & REBA method $^{16)}$ & INSHT method ${ }^{21)}$ \\
\hline "Job Strain Index" method"11) & OWAS method ${ }^{17)}$ & NIOSH equation ${ }^{22)}$ \\
\hline Posture and Repetition Risk Factor Index (PRRI) ${ }^{12)}$ & Corlett method ${ }^{18)}$ & Snook and Ciriello tables ${ }^{23)}$ \\
\hline IBV method $^{13)}$ & Vira method ${ }^{19)}$ & KIM method ${ }^{24)}$ \\
\hline OCRA method ${ }^{14)}$ & PATH method ${ }^{20)}$ & MAC method ${ }^{25)}$ \\
\hline PLIBEL method ${ }^{15)}$ & & Liberty Mutual tables ${ }^{26)}$ \\
\hline
\end{tabular}

EU-OSHA $^{2)}$ defines them as "alterations suffered by body structures such as muscles, joints, tendons, ligaments, nerves, bones, and the circulatory system, caused or aggravated mainly by work and the effects of the surroundings in which this is undertaken". These disorders can arise in any part of the body, although they are more frequent in some zones.

The International Labour Organization ${ }^{8)}$ defines the musculoskeletal system as being made up of "two components, the muscular system and the skeletal system". It establishes musculoskeletal disorders as "acute, chronic, and those that can impair the function of different body parts". It states that the work itself triggers the musculoskeletal disorders, depending on the workplace and the worker.

The prevention of MSD involves the analysis of the work to be done and to determine the risk factors in order to apply a series of preventive measures ${ }^{1,2)}$. In this sense, the factors that increase the risk of $\mathrm{MSD}^{9)}$ can be grouped into two types, i.e. those based on physical aspects of the work (loads, bad postures, repetitive movements, physical exertion, mechanical pressure on bodily tissues, cold working conditions, body vibrations) and those based on the work environment and work organization (pace of work, repetition of tasks, work timetable, remuneration systems, job monotony, fatigue, worker perception of job organization, and psychosocial factors). In turn, the European Agency for Safety and Health at Work ${ }^{2,3)}$, classifies these factors into physical, biomechanical, organizational, and psychosocial, individual, and personal categories.

\subsection{Musculoskeletal disorders}

\subsubsection{Evaluation methods}

Methods for analysing work vary depending on the means available in each company, from checklists (with all the possible factors) to sophisticated methods of movement analysis (infrared, ultrasound, etc.). For the study and evaluation of MSD, it is possible to use different methods for which classification could be simplified into direct, semi-direct, or indirect methods.

\subsubsection{Direct methods}

These consist of using certain electronic devices on the human body to measure work postures. Specifically, these sensors record the angles, distances, and the velocities of elements to be analysed. Precision, exactitude, practically automatic data gathering, and the possibility of monitoring the different variables over time are the most notable advantages. The main drawbacks include the high economic cost and the difficulty of using these methods in real time for many work environments due to the discomfort of working with the sensors operating. This is exacerbated when the sensors require cords.

\subsubsection{Semi-direct methods}

These are based on the use of computer programs that enable the evaluation of postures and therefore of musculoskeletal risks. The use of the software requires prior examination of the postures adopted by the workers, normally by video recording or photography.

In these cases, precision is lower than in the direct methods. However, the indirect methods are more economical although they usually require licences of computer programs. The evaluation with these methods takes more work time with respect to the direct methods, primarily because of the subsequent interpretation of the videos and/ or photographs.

Table 1 shows a partial classification of the semi-direct methods according to the type of cause of the MSD.

\subsubsection{Indirect methods}

Indirect methods are based on the use of questions that are complemented by the worker and/or evaluator. These methods have been developed and tested by research centres or specialized researchers. The advantages of these methods are principally their low cost and more or less confirmed reliability. However, the complexity on occasions, the statistical treatment of the data and the need to administer questionnaires to a representative portion of the workers under study are the main disadvantages.

Some of the best-known questionnaires include those of Michigan ${ }^{27}$, the famous Standardised Nordic Questionnaires for the Analysis of Musculoskeletal Symptoms ${ }^{28)}$, 


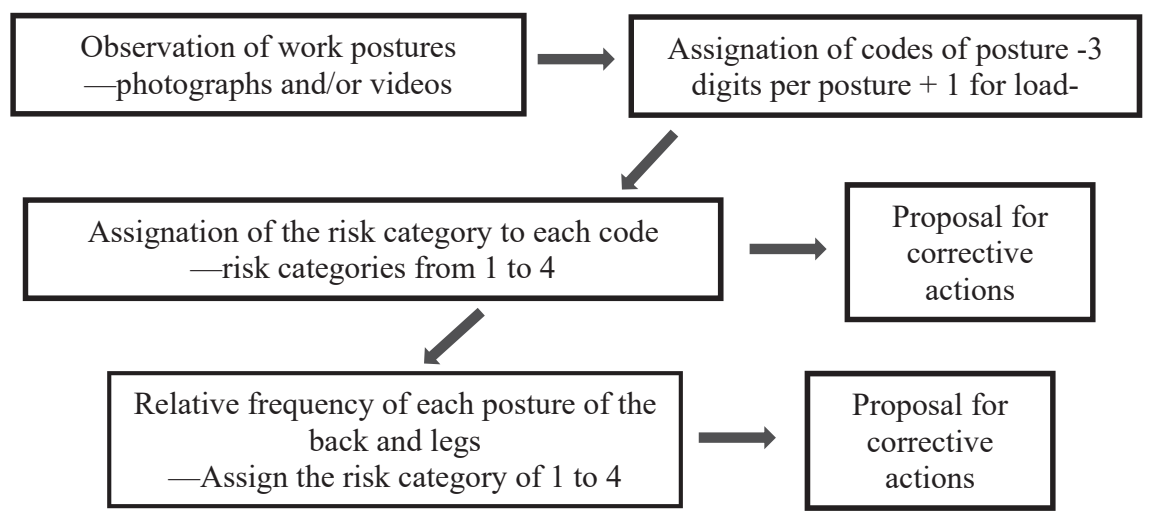

Fig. 1. Flow diagram of the OWAS-application process.

the questionnaire of Keyserling, Brouwer, and Silver$\operatorname{stein}^{29)}$, that of Keyserling ${ }^{30)}$, and the Quick Exposure Check $^{31)}$. Also, in this section, the scale of Borg ${ }^{32)}$ could be included since it is not properly a questionnaire but is not a direct or semi-direct method, either.

\subsubsection{The OWAS method}

\subsubsection{Inception of the OWAS}

The Ovako Working Posture Assessment System (OWAS) was formulated in Finland, specifically in the OVAKO OY company, a leading European producer of steel bars and profiles. This system was used to evaluate the work load in the repair process of smelting furnaces ${ }^{33}$.

The OWAS was initially created with the identification of 72 postures established by photographing the work postures used in different working areas in OVAKO OY. It reliability was confirmed by the analysis of several tasks by a group of engineers (national and international) previously trained in the method. For this, the observations were made by two engineers on two workers during two different work shifts (morning and afternoon). The results found by both groups were roughly similar. Afterwards, they established four risk categories, the first being related to normal postures without recommendations of any type for corrective activity. The second and third categories concerned postures with some risk with recommendations for corrective actions to be taken over the middle term. The fourth category referred to unacceptable postures with recommendations for immediate corrective measures ${ }^{17}$.

\subsubsection{The method}

The OWAS method was intended to identify the frequency and time spent in the postures adopted in a given task, to study and evaluate the situation, and thus, recommends corrective actions ${ }^{17}$. The OWAS identifies the most habitual back postures in workers (4 postures), arms (3 postures), legs (7 postures) and weight of the load handled ( 3 categories). All this implies up to 252 possible combinations. Therefore, each posture assumed by a worker was assigned a 4-digit code that depended on the classification within the previous postures for each part of the body and the load ${ }^{33)}$.

The procedure to apply the OWAS consisted of making observations of the work tasks, codifying the postures, assigning risk categories and proposing corrective actions (Fig. 1).

There are different computer programs which have able to apply this method, allowing saving time of work, and which have been already used in several studies ${ }^{34-37)}$.

\subsubsection{Advantages}

It is a simple and useful method, can be used by personnel of different spheres, such as health, engineering, industry, etc., without specialized training ${ }^{17)}$ and is well documented $^{33)}$.

\subsubsection{Limitations}

Several authors neither differentiated the right from left upper limbs, nor evaluated the parts of the body such as the neck, elbows, and wrists, posture coding crude for shoulders, excessive time for its application, and did not take into account repetition or duration of the sequential postures $^{33)}$.

\subsection{Objective}

The objective of the present work is to review the literature on the applications of the OWAS method ${ }^{17)}$ in the diverse sectors or fields of knowledge and countries from December 1977 to March 2017.

\section{Subjects and Methods}

A great number of methods are known, as well as their 
advantages and disadvantages, for evaluating the load posture of workers during a given task, but one of the most commonly used and widely endorsed methods in different studies for multiple work environments such as medicine, the oil industry, and agriculture is the OWAS ${ }^{17}$. This studies have been made by researchers with varied profiles, from doctors to engineers ${ }^{33,38-40)}$.

For the purposes of the present work, the literature was thoroughly reviewed. The data were gathered through electronic access that the Library of the University of Almería, offer through the Spanish Foundation for Science and Technology (FECYT), which in turn manages the Spanish licensing of the "Web of Science" (Wos) provided by Thomson Reuters ${ }^{41)}$. The search was made by selecting only the main collection of the Web of Science. This was selected by the option "Advanced search" using the term OWAS (ts=OWAS) for the time period of 1900 to 2017. A total of 166 results were found, consisting of conference papers and articles in scientific journals. Of these 166 results, the relevant articles according to the title and abstract were initially selected, excluding those that, despite including the term OWAS, did not concern work health and safety. The final material centred on the period of 1981 to March 2017, dates for the first and last document related to this method.

As limitations of the literature search, some citations might have been overlooked with the search procedure used (only TS=OWAS). Also, the search was made first in the main collection of the Wos without considering other complementary data bases. Also, on considering only articles from conferences and scientific journals, work from books, book chapters, or other formats were disregarded.

As incidents during the search, documents with the same content were detected, these being reprints or papers from conferences later published in scientific journals. Therefore, only the original article was considered. Also, some articles found did not concern the application or the use of the OWAS method in a given sector or with a specific purpose, but subjects related to labour health and safety, and therefore were eliminated for not being a direct application. Finally, other articles have applied the OWAS method to different fields involving several types of workers. In these few cases, they were assigned to the field of knowledge with the highest number of workers studied.

\section{Results and Discussion}

\subsection{By categories of knowledge}

Works published in different fields of knowledge ${ }^{42)}$ are based on analyses of work postures during different tasks and identify the discomfort or injuries provoked by incorrect posture.

A total of 12 work environments have been identified. The fields of knowledge in which the OWAS has been applied go from "Manufacturing industries", with a total of 34 published articles, to "Administrative and support services activities" or "Accommodation and catering activities", with just one study each (Fig. 2).

\subsubsection{Healthcare and social assistance activities}

Several health disciplines in which the OWAS was applied are summarized in Table 2.

\subsubsection{Surgery}

Several authors used the OWAS model for surgery personnel (nurse's aids, nurses, and surgeons), belonging to general surgery and the ear-nose-and-throat specialty. These authors concluded that surgeons and nurses assume harmful postures ${ }^{43}$. Kulagowska ${ }^{44)}$ also studied the postures adopted by nurses administering anaesthetics, concluding that the musculoskeletal problems were determined by the organization of the tasks. One year later, Kulagowska ${ }^{45}$ ) found similar results for nurses in surgery, leading to the same conclusions. Other authors ${ }^{46)}$ applied the OWAS together with the RULA method ${ }^{10)}$ to evaluate the postures required by the new surgical table for hips, knees, and spinal column. Finally, Bartnicka ${ }^{47)}$ analysed the tasks of nurses and surgeons through a number of methods, including the OWAS, enabling comparisons between methodologies.

\subsubsection{Ophthalmology}

Different authors ${ }^{48}$ assessed the postures carried out by ophthalmology staff using OWAS method, making suggestions to improve the taken postures.

\subsubsection{Nursing}

This is the health field where the OWAS method has most widely been used. For example, Engels et al. ${ }^{49)}$ applied it to nurses belong to the field of orthopaedics and urology, discovering that the postures adopted over a large part of the work day were harmful. In this same year, Hignett ${ }^{50)}$ used the same method with the help of computer software, thereby reducing the analysis time of the results.

In nurses specialized in geriatrics the method was also used, reflecting that the tasks of moving the patients resulted in the greatest percentage of strained postures ${ }^{51)}$. Several authors ${ }^{52,53)}$ evaluated the postures adopted by nurses before and after receiving training courses. These authors concluded that the training had helped to diminish the amount of strained postures assumed during the work 


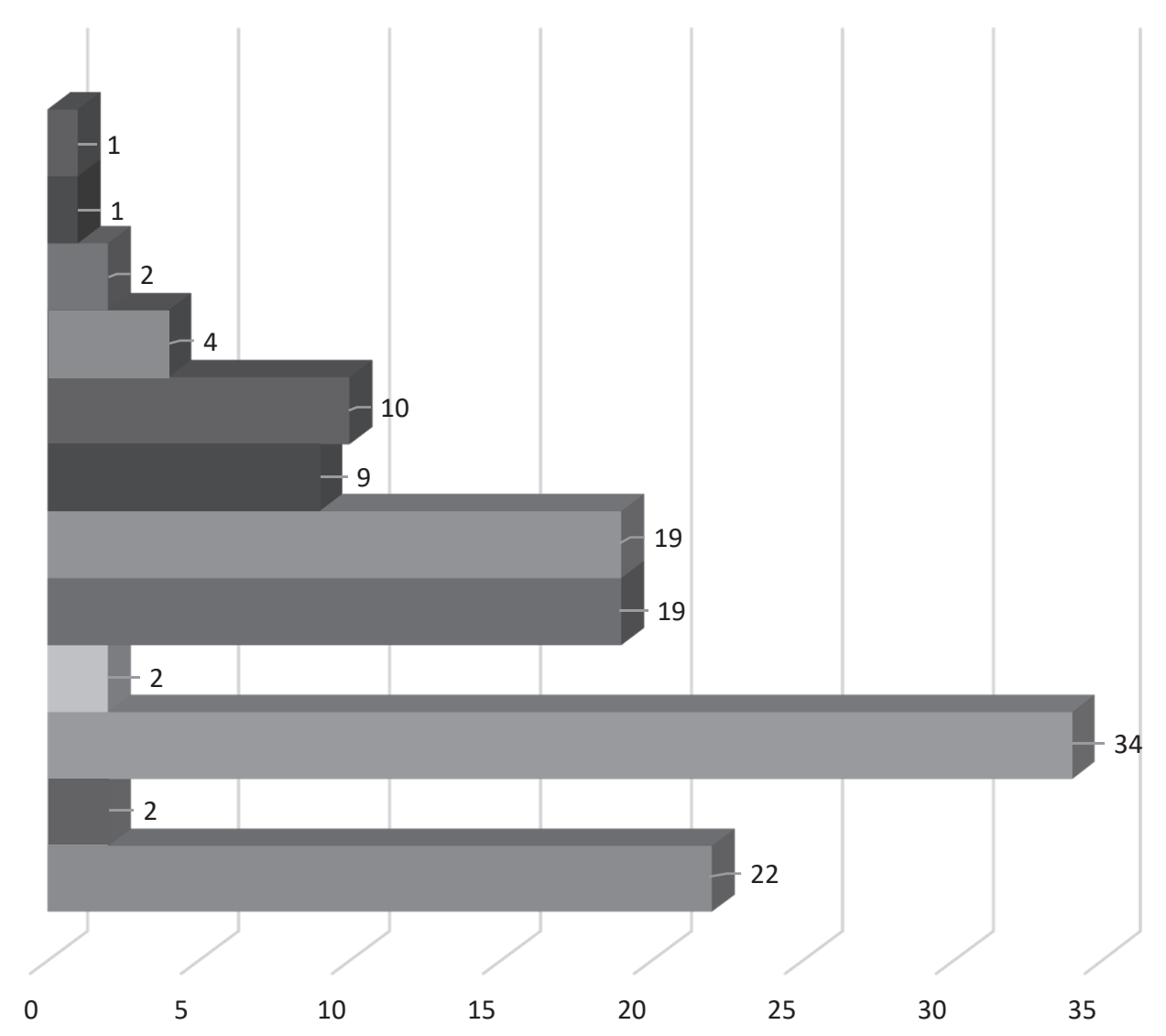

- Administrative and support services activities

- Accommodation and catering activities

Wholesale and retail trade; motorcycles and motor vehicles reparation

$\square$ Teaching

- Transportation and storage

- Construction

- Information and communications

- Agriculture, livestock, forestry, and fishing

Mining and quarrying

Manufacturing industries

- Housework activities as employers; non differed housework activities as good and services producers for their own use

- Healthcare and social assistance activities

Fig. 2. Publications by field of knowledge.

day.

Other authors ${ }^{54}$ used the OWAS to verify the reliability of the observations based on this method, using a compilation of the postures observed in nursing. Stricevic et $a l .{ }^{55)}$ evaluated the postures of nurses working without the use of mechanical equipment to aid in the tasks, and com- pared these postures to those adopted when using mechanical equipment. These authors concluded that the use of mechanical equipment diminished the number of strained postures.

The OWAS has also been used with midwives while assisting in childbirth, together with other methods and 
Table 2. Healthcare and social assistance activities

\begin{tabular}{|c|c|c|c|c|}
\hline References & Location & Date & Objective & Section \\
\hline 43) & Netherlands & 1992 & Application of the OWAS in surgery personnel. & 3.1 .1 .1 \\
\hline 50$)$ & England & 1994 & Application of the OWAS by computer in nurses. & 3.1.1.3 \\
\hline 49) & Netherlands & 1994 & Application of the OWAS in nurses in orthopaedics and urology. & 3.1.1.3 \\
\hline 60$)$ & Netherlands & 1995 & Application of the OWAS and other ergonomic tool in ambulance workers. & 3.1 .1 .5 \\
\hline 51$)$ & England & 1996 & Application of the OWAS in nurses caring for the aged. & 3.1.1.3 \\
\hline 52) & Australia & 1997 & Application of the OWAS in an evaluation of the training received by nurses and caretakers. & 3.1.1.3 \\
\hline 53) & Netherlands & 1998 & $\begin{array}{l}\text { Application of the OWAS, monitoring list to measure errors committed and Borg scores in the evalua- } \\
\text { tion of an ergonomic source for nurses. }\end{array}$ & 3.1.1.3 \\
\hline 54) & Netherlands & 1998 & Evaluation of the reliability of the OWAS observations concerning postures adopted by nurse. & 3.1.1.3 \\
\hline 58) & England & 1998 & Application of the OWAS, questionnaire and the Borg scale RPE in nursery-school staff. & 3.1.1.4 \\
\hline 61) & Canada & 2003 & Application of the OWAS and other techniques in workers at a rehabilitation centre. & 3.1 .1 .5 \\
\hline 44) & Poland & 2008 & Application of the OWAS in nurses working in anaesthesia. & 3.1.1.1 \\
\hline 45) & Poland & 2009 & Application of the OWAS in nurses during surgery. & 3.1.1.1 \\
\hline 55) & Slovenia & 2009 & $\begin{array}{l}\text { Application of the OWAS in a study examining the advantages of using ergonomic equipment in nurs- } \\
\text { ing. }\end{array}$ & 3.1.1.3 \\
\hline 46) & Germany & 2009 & $\begin{array}{l}\text { Development of a positioning system of a surgery table and evaluation of postures with the OWAS and } \\
\text { RULA. }\end{array}$ & 3.1.1.1 \\
\hline 56) & Poland & 2012 & Application of several ergonomic tools, including the OWAS, for midwives. & 3.1.1.3 \\
\hline 62) & Brazil & 2012 & Application of the OWAS and RULA, Corlett poll and questionnaire in radiologists. & 3.1 .1 .5 \\
\hline 59) & Brazil & 2012 & Application of the OWAS in nursery-school workers. & 3.1.1.4 \\
\hline 63) & Spain & 2013 & Application of the OWAS in workers with mental disabilities. & 3.1.1.5 \\
\hline 57$)$ & Slovenia & 2014 & Application of the OWAS and computer simulation in nurses in ophthalmology. & 3.1.1.3 \\
\hline 47) & Poland & 2015 & Application of several methods, including the OWAS, in surgery personnel (nurses and surgeons). & 3.1.1.1 \\
\hline 64) & Italy & 2015 & Application of the OWAS and other techniques to design the e-Health station. & 3.1.1.5 \\
\hline 48) & Slovenia & 2015 & Application of the OWAS in ophthalmology staff. & 3.1.1.2 \\
\hline
\end{tabular}

support questionnaires. It was concluded that the midwives suffered back pain from adopting incorrect postures ${ }^{56)}$.

Finally, the method has also been applied to nurses working in the area of ophthalmology with the help of computer software. Certain incorrect postures were found and short-term corrective actions were proposed ${ }^{57)}$.

\subsubsection{Nursery schools}

Crawford and Lane ${ }^{58)}$ used the OWAS together with an MSD questionnaire and the Borg scale to evaluate the staff of a nursery school. The strained postures were found primarily during the play activities and meal supervision.

Also, several authors ${ }^{59)}$ evaluated a group of nursery teachers using the OWAS and a questionnaire. These authors demonstrated that, even though the teachers were mostly standing, they adopted strained postures of bending, leaning laterally, and rotating the trunk.

\subsubsection{Other fields}

Doormaal et al. ${ }^{60)}$ using the OWAS, studied the physical load in ambulance workers by a biomechanical analysis and a questionnaire on work and health. Different harmful postures were detected, the most serious occurring during emergencies.

The OWAS was also used in combination with other methods in workers at a rehabilitation centre. In this case, only the tasks of the staff were evaluated, these consisting of folding and unfolding wheelchairs. It was concluded that in many cases the postures adopted could be harmful and generate musculoskeletal injuries ${ }^{61)}$.

Other authors ${ }^{62)}$ used the OWAS together with RULA and the Corlett questionnaire in radiologists of a hospital in Rio de Janeiro. One of the main conclusions was that the staff suffered MSD due to the adoption of strained postures during the work day.

Diniz-Baptista ${ }^{63)}$ evaluated tasks of gardening, ironing, etc. among workers with mental disabilities. These authors used the OWAS, RULA, and the NIOSH equation (Table 1). The great presence of MSD was evidenced as a consequence of strained postures, especially of the back.

Finally, OWAS was applied together with other methods into a study to design an eHealth technology station (a virtual interactive tool about health), which was going to be available on pharmacies. For this, the postures that patients should be taking in this place were analysed. The goal of this technology was to improve some issues like management, organization, etc ${ }^{64)}$.

In all these cases, the study within the sphere of health 
Table 3. Housework activities as employers; non differed housework activities as good and services producers for their own use

\begin{tabular}{ccccc}
\hline References & Location & Date & Objective & Section \\
\hline 65$)$ & Finland & 1998 & Application of the OWAS in women caring for patients at home. & 3.1 .2 \\
$66)$ & Turkey & 2008 & Application of the OWAS to evaluate postures of mothers of disabled children. & 3.1 .2 \\
\hline
\end{tabular}

has found strained postures. This fact suggests that the method is overly sensitive in detecting risk or that work related to the field of health requires short- to mediumterm improvement. These improvements could be made from innovation in the auxiliary mechanical equipment adapted to each task of health workers.

3.1.2. Housework activities as employers; non differed housework activities as good and services producers for their own use

In Table 3 there is a summary of the existing studies in this field.

Only two researches related to this field have been carried out in the period of time analysed.

Pohjonen et al. ${ }^{65)}$ used the method to evaluate women who cared for disabled persons in private homes. The results helped to propose corrective action that diminished the adoption of strained postures.

Similarly, Tonga and Duger ${ }^{66)}$ applied the OWAS and another auxiliary method to improve the positions adopted by mothers who assisted their disabled children. Furthermore, they detected the lack of training among such mothers.

\subsubsection{Manufacturing industries}

Table 4 shows the studies in industry where the OWAS was used.

\subsubsection{Steel}

Several authors ${ }^{17,67)}$, in the steel industry, proposed a new evaluation method (OWAS) and afterwards implemented corrective actions in different jobs. Later, Burdorf et al. ${ }^{68)}$ evaluated two groups of workers. The larger group worked in maintenance and the other in transport. The researchers evaluated the bending of the torso with two methods to make comparisons. One was by the OWAS and the other by a sensor on the back. Major differences were found between the two methods, and the results of the evaluation.

Finally, in the works of welding, Horvat et al. ${ }^{69)}$ investigated the conditions to which the welders were exposed, in a study with the OWAS and the Corlett method ${ }^{18)}$. These authors concluded that welders suffer discomfort and pain as a consequence of strained postures, proposing corrective measures.

\subsubsection{Paper and wood}

Several researchers ${ }^{70,71)}$ used the OWAS to evaluate the postures of workers in the paper and wood industries, respectively. In the former case, the method was applied by a computer in workers in charge of multiple tasks. In the second case, after the OWAS was applied, modifications were made in the workplace and the ways of approaching the tasks.

Gilkey et al. ${ }^{72)}$ investigated lumbago in carpenters and their risk factors. These authors used the OWAS with the support of computer tools. The results showed that more than half of the tasks studied surpassed the load limit for the lumbar established by NIOSH ${ }^{22}$.

On the last available study, Hussain et al. ${ }^{73)}$ studied how the workers abilities influenced in a furnishing factory on their tasks, and made an evaluation of the postures using OWAS y REBA ${ }^{16)}$. This showed that a $33 \%$ of the postures were grave and an immediate correction was suggested.

\subsubsection{Chemistry}

Vayrynen et $\mathrm{ll}^{74)}$ studied workers in charge of maintenance in two chemical plants. The OWAS identified a large number of strained postures. These facts account for the musculoskeletal problems in several areas of the body of the workers. Vedder ${ }^{75)}$ applied the OWAS in a chemical plant, using videos of the tasks performed by workers, identifying incorrect postures for the back and head. Finally, in the furniture-manufacturing industry using plastic injection, located in India, Sanjog et al. ${ }^{76)}$ analysed the postures of the worker in relation to musculoskeletal ailments in those workers. These researchers used photograph, the OWAS, REBA ${ }^{16)}$, and the standardized Nordic questionnaire ${ }^{28)}$ and concluded that the production staff suffered more MSD than did the other workers.

\subsubsection{Agrofood}

Evangelista et al. $^{77)}$ applied the OWAS to workers performing different meat-processing tasks in Brazil. These authors concluded that in the canning tasks correct shortterm actions were necessary. Afterwards, in the same agrofood industry, focusing on cutting up meat, Evangelista and Borges ${ }^{78)}$ detected strained postures and proposed cor- 
Table 4. Manufacturing industries

\begin{tabular}{|c|c|c|c|c|}
\hline References & Location & Date & Objective & Section \\
\hline 67) & Finland & 1981 & Application of the OWAS in steel workers. & 3.1.3.1 \\
\hline 70) & Finland & 1992 & Application of the OWAS by computer for workers in the paper industry. & 3.1.3.2 \\
\hline 68) & Netherlands & 1992 & $\begin{array}{l}\text { Analysis of several working bending at the trunk, by applying the OWAS and a measuring device } \\
\text { placed on an area of the body. }\end{array}$ & 3.1.3.1 \\
\hline 71) & Netherlands & 1993 & Application of the OWAS method in workers in the wood industry. & 3.1.3.2 \\
\hline 74) & Finland & 1994 & Application of the OWAS in maintenance workers at two chemical plants. & 3.1.3.3 \\
\hline 89) & Netherlands & 1997 & Application of the OWAS in male workers in ship maintenance. & 3.1.3.7 \\
\hline 75) & Germany & 1998 & Application of the OWAS in workers at a chemical plant. & 3.1.3.3 \\
\hline 90) & United States & 2001 & Application of the OWAS, for RPE and BPD measurements in workers carrying boxes. & 3.1.3.7 \\
\hline 83) & Slovenia & 2003 & $\begin{array}{l}\text { Experimental design of the workplace for sewing designed ergonomically, using several methods, } \\
\text { including the OWAS. }\end{array}$ & 3.1 .3 .5 \\
\hline 91) & South Korea & 2007 & $\begin{array}{l}\text { Application and comparison of the OWAS, RULA, and REBA in workers in several industries a hos- } \\
\text { pital. }\end{array}$ & 3.1.3.7 \\
\hline 69) & Slovenia & 2007 & Analysis by the OWAS and other methods in soldiers. & 3.1.3.1 \\
\hline 72) & United States & 2007 & Application of the OWAS and the software ErgoMaster (TM)2D to investigate lumbago in carpenters. & 3.1.3.2 \\
\hline 92) & United States & 2009 & Application of the OWAS in obese maintenance workers. & 3.1.3.7 \\
\hline 94) & Cuba & 2011 & $\begin{array}{l}\text { Use of several methods, including the OWAS, for an ergonomic analysis in several sectors of industry } \\
\text { and tourism. }\end{array}$ & 3.1.3.7 \\
\hline 93) & South Korea & 2011 & $\begin{array}{l}\text { Study of the introduction of safety and health regulations in the workplace in the motor industry by } \\
\text { ergonomic evaluations. }\end{array}$ & 3.1.3.7 \\
\hline 96) & Thailand & 2012 & The OWAS, REBA, and RULA applied in workers producing rubber sheets. & 3.1.3.7 \\
\hline 81) & India & 2012 & Application of several tools, including the OWAS, to investigate the workers of the jute industry. & 3.1.3.4 \\
\hline 77) & Brazil & 2012 & Application of the OWAS in workers of the pig industry. & 3.1.3.4 \\
\hline 79) & India & 2012 & $\begin{array}{l}\text { Measurement of parameters, the OWAS and Nordic methods in women who dice and grind fruit } \\
\text { (Aonla). }\end{array}$ & 3.1.3.4 \\
\hline 80) & India & 2012 & $\begin{array}{l}\text { Application of the OWAS, RULA, and a scale of perceived effort in workers who dice and grind fruit } \\
\text { (Aonla). }\end{array}$ & 3.1.3.4 \\
\hline 84) & India & 2014 & Application of the OWAS and questionnaires of weavers using handlooms. & 3.1.3.5 \\
\hline 78) & Brazil & 2015 & Application of the OWAS in workers of the pig industry. & 3.1.3.4 \\
\hline 37) & Indonesia & 2015 & Questionnaire NBM and software WinOWAS in workers of a corn-chip factory. & 3.1.3.4 \\
\hline 76) & India & 2015 & Use of several tools, including the OWAS in furniture builders. & 3.1.3.3 \\
\hline 97) & Portugal & 2015 & $\begin{array}{l}\text { Application of QEC, REBA, and the OWAS in workers in tasks related to electric and electronic } \\
\text { equipment. }\end{array}$ & 3.1.3.7 \\
\hline 98) & Germany & 2015 & Use of body sensors to ergonomic analysis on industry, allowing OWAS and EAWS assessments. & 3.1.3.7 \\
\hline 85$)$ & Turkey & 2015 & Application of the OWAS in workers producing materials for tyres. & 3.1.3.6 \\
\hline 95) & Taiwan & 2016 & $\begin{array}{l}\text { Application of the OWAS method and other ergonomic tools in workers of the TFT-LCD manufactur- } \\
\text { ing industry. }\end{array}$ & 3.1.3.7 \\
\hline 86) & Turkey & 2016 & Application of the OWAS in workers producing materials for tyres. & 3.1.3.6 \\
\hline 82) & Iran & 2016 & Application of the OWAS and other methods in food industry workers. & 3.1.3.4 \\
\hline 87) & Poland & 2016 & Application of the OWAS in automobile industry workers. & 3.1.3.6 \\
\hline 73) & England & 2016 & Application of the OWAS and REBA in a furniture factory workers. & 3.1.3.2 \\
\hline 99) & Iran & 2017 & $\begin{array}{l}\text { Application of the OWAS, RULA, REBA, PATH, QEC and Nordic Musculoskeletal Questionnaire, in } \\
\text { industry workers. }\end{array}$ & 3.1.3.7 \\
\hline 88) & Germany & 2017 & Application of the OWAS in workers assembling semi-trailers. & 3.1.3.6 \\
\hline
\end{tabular}

rective actions over the short and long term.

Several authors ${ }^{79,80)}$ studied problematic posture for workers that diced fruit in the cultivations of Aonla (Phyllanthus emblica L.) in India. These researchers sought to verify whether the introduction of mechanical equipment for dicing the fruit improved the traditional labour done by hand. For this, in the first study, using the OWAS together with the standardized Nordic questionnaire ${ }^{28)}$, the heart rate was measured and evaluated, but only in women. In the second study, the OWAS, RULA ${ }^{10)}$, and a questionnaire of perceived effort (scale) was used without distinguishing between sexes. In both cases, it was concluded that the mechanical equipment diminished the adoption of strained postures. 
Sett and Sahu ${ }^{81)}$ used the method in the jute industry, considering only male workers. They concluded that there was a direct relation between strained postures adopted and the MSD suffered by the workers.

Other authors ${ }^{37)}$ used OWAS, using computer tools and additional questionnaires, in an industry of corn-chip production. It was found that the four risk categories of the OWAS (from the lowest to the highest) occurred during the analysis of postures adopted in each task.

Finally, Naeini et al. ${ }^{82)}$ assessed a food industry workers using OWAS. They deduced that the design of a wheelbarrow which could improve the ergonomic conditions was convenient.

\subsubsection{Textiles}

Two sewing workshops were analysed by Polajnar and Caks ${ }^{83)}$ using the OWAS and other complementary methods. These researchers concluded that workplaces previously designed for textile work result in the least number of strained postures by the workers. On the other hand, Durlov et al. ${ }^{84)}$ investigated lumbago among workers using handlooms in India. The authors used a series of questionnaires in addition to the OWAS. The results showed that over half of the workers suffered lumbago with different degrees of severity.

\subsubsection{Vehicles}

In two studies ${ }^{85,86)}$, OWAS method was used to evaluate the postures of workers in charge of producing materials for tyres manufacture. Also, they suggested measures to correct injuring postures.

Other authors ${ }^{87}$, also used it to evaluate staff working with spot welding machines on the automobile industry. The study focused on 45 workers, men and women, proposing some improvements. As well, Brandl et al. ${ }^{88)}$ applied the method to assess postures of workers in charge of assembling semi-trailers, and suggested new prevention programs.

\subsubsection{Others}

The first study in this section is based on the posture analysis, using the OWAS, of workers (only males) in the maintenance of ships belonging to two companies. Harmful postures were detected and excessive effort in some tasks ${ }^{899}$.

Olendorf and Drury ${ }^{90)}$ used the method to evaluate workers carrying boxes. In addition, these authors used biomechanical methods to complement OWAs. The results showed strained postures as a consequence of the weight of the boxes.

Kee and Karwowski ${ }^{91)}$ applied the OWAS in several industries (electronics, automotive, steel and chemicals) as well as in a hospital. They also used the methods RULA ${ }^{10)}$ and REBA ${ }^{16)}$ to compare the three methods in different work environments. It was concluded that the OWAS and REBA gave similar results whereas RULA gave overestimations with respect to the other two.

Park et al. ${ }^{92)}$ using the OWAS and a biomechanical evaluation method, investigated the influence of obesity in static maintenance tasks. These researchers concluded that obesity was a more limiting factor in the adoption of strained postures.

Other authors ${ }^{93)}$ undertook a study seeking to diminish the MSD of workers in the automotive industry of South Korea (complying with the regulations of the country on work health and safety). A similar study was made in Cuba, in the tourist sector, tobacco industry, pharmaceutical industry, and biotechnology ${ }^{94)}$. In turn, Lu et al. ${ }^{95)}$ made a comparable study in Taiwan in the industrial electronics sector (manufacture of liquid-crystal displays). All of these researchers used the OWAS and other complementary methods, proposing corrective measures.

In the rubber industry, the OWAS was applied together with RULA ${ }^{10)}$ and REBA ${ }^{16)}$. The results of the three methods established that the postures adopted by the workers were harmful ${ }^{96)}$

Other authors ${ }^{97)}$ applied the OWAS together with the QEC method (Table 1) to workers related to the use of electric and electronic equipment. Injuring postures were detected and some measures were suggested.

Also in the industrial sector, Di Valentin et al. ${ }^{98)}$ developed a system to make ergonomic evaluations to workers by using sensors on their bodies, so that, they got immediate results about the performed postures. With this system, evaluations of methods like OWAS and EAWS were possible.

Finally, Yousefi et al. ${ }^{99)}$ studied musculoskeletal disorders on Iranian workers of the industrial field. They used information from different studies and reports. They used OWAS method together with other methods like RULA ${ }^{10)}$, REBA $^{16)}$, PATH ${ }^{20)}$, QEC (Quick Exposure Check) and Nordic Musculoskeletal Questionnaire ${ }^{28)}$. Disorders on knees and back were the main disorders detected.

As in the health field, each time that the OWAS was applied, strained postures were found to a greater or lesser degree. Also, many authors have used the OWAS together with other semi-direct methods (e.g. RULA and REBA; Table 1) and indirect ones (standardized Nordic questionnaire). This finding suggests that the OWAS alone might not be sufficient for the evaluation of strained postures and needs complementary data, mainly for its limitations. 
Table 5. Mining and quarrying

\begin{tabular}{ccccc}
\hline References & Location & Date & Objective & Section \\
\hline 100$)$ & Italy & 2009 & Application of the OWAS in quarry workers. & 3.1 .4 \\
$101)$ & India & 2010 & Application of the OWAS in quarry workers. & 3.1 .4 \\
\hline
\end{tabular}

Table 6. Agriculture, livestock, forestry, and fishing

\begin{tabular}{|c|c|c|c|c|}
\hline References & Location & Date & Objective & Section \\
\hline 102) & Netherlands & 1989 & Choice of the OWAS to evaluate work postures in agriculture. & 3.1.5.1 \\
\hline 103) & Finland & 1995 & $\begin{array}{l}\text { Application of the OWAS to evaluate work postures after rehabilitation courses in women farmers, as } \\
\text { well as to conclude whether the procedure was favourable. }\end{array}$ & 3.1.5.1 \\
\hline 120) & Scotland & 1996 & Application of the OWAS in the poultry industry. & 3.1.5.2 \\
\hline 104) & Finland & 1996 & Application of the OWAS and other techniques to evaluate rehabilitation for farmers. & 3.1.5.1 \\
\hline 116) & Finland & 1996 & Application of the OWAS, and measurements of certain parameters in workers in milking sheds. & 3.1.5.2 \\
\hline 117) & Sweden & 1999 & Application of the OWAS in workers milking cows. & 3.1.5.2 \\
\hline 118) & Finland & 2005 & $\begin{array}{l}\text { Application of the OWAS and measurement of other parameters for workers in stanchions and in free- } \\
\text { ranging dairy cows. }\end{array}$ & 3.1.5.2 \\
\hline 119) & Poland & 2011 & Application of the OWAS in dairy farmers. & 3.1.5.2 \\
\hline 112) & Brazil & 2012 & Application of the OWAS workers producing charcoal. & 3.1.5.1 \\
\hline 107) & Brazil & 2012 & Application of the OWAS in workers in a eucalyptus nursery. & 3.1.5.1 \\
\hline 108) & Brazil & 2012 & Application of EAW methodology y use of WinOWAS in sugar-cane cutters. & 3.1.5.1 \\
\hline 106) & Brazil & 2012 & Application of several methods, including the OWAS, in workers raising organic vegetables. & 3.1.5.1 \\
\hline 105) & Japan & 2012 & Application of the OWAS in vineyard workers. & 3.1.5.1 \\
\hline 110) & India & 2013 & $\begin{array}{l}\text { Application of REBA, the OWAS, the standardized Nordic questionnaire, and measurement of other } \\
\text { parameters of children doing farm work. }\end{array}$ & 3.1.5.1 \\
\hline 111) & Austria & 2014 & Application of the OWAS, interview and measurement of parameters of workers picking apples. & 3.1.5.1 \\
\hline 113) & Malaysia & 2015 & Application of the OWAS in harvesters of oil-palm fruit. & 3.1.5.1 \\
\hline 36) & Brazil & 2015 & $\begin{array}{l}\text { Application of a software of the OWAS method and another technique in workers raising meat chick- } \\
\text { ens. }\end{array}$ & 3.1.5.2 \\
\hline 114) & Colombia & 2016 & Application of the OWAS in workers of rubber harvesting and rubber industry. & 3.1.5.1 \\
\hline 115) & Japan & 2017 & Application of the OWAS in harvesters of asparagus. & 3.1.5.1 \\
\hline
\end{tabular}

Since the 1990s, computer tools began to be used to interpret the images taken of different tasks of the workers evaluated, and this substantially shortened the evaluation times.

\subsubsection{Mining and quarrying}

Table 5 shows studies available about mining and quarrying.

Several authors ${ }^{100,101)}$ applied the OWAS to quarrying. The former authors observed the postures adopted by the workers on including two mechanical pieces of equipment in their tasks. The conclusion was that the use of the auxiliary equipment resulted in better work postures. The latter research team demonstrated that the strained postures detected during the tasks affected primarily the lumbar zone, the knees, and the shoulders.

\subsubsection{Agriculture, livestock, forestry, and fishing.}

Table 6 shows the different works related to agriculture, livestock, forestry, and fishing.

\subsubsection{Agriculture}

Vanderschilden ${ }^{102)}$ of the Netherlands selected the OWAS, among other semi-direct methods (Table 1), as the most favourable to evaluate the postures of farmers, above all for its simple application.

NevalaPuranen ${ }^{103,104)}$ used the OWAS with the help of computer tools in a group of farmers who had previously received training (rehabilitation course). In the first study (in 1995) it was applied only to female workers, while in the second (in 1996), it was used with males and females in addition to using other semi-direct evaluation methods (Table 1). In both cases, a reduction was found in strained postures and therefore a reduction in MSD. Furthermore, new ways of completing the tasks were recommended.

Another study was made in Japan, in vineyards. The postures of workers were evaluated by the OWAS with and without robotic machinery. It was found that the pruning work gave rise to greater workloads than did fruit thinning, 
regardless of the terrain (sloped or level). Nevertheless, in both cases, the posture load was greater when the land was sloped. It was concluded that fewer strained postures resulted with robotic machinery ${ }^{105)}$.

In horticultural crops, Abrahao et al. ${ }^{106)}$ used the OWAS together with an adaptation of the PATH method ${ }^{20)}$, the Corlett method ${ }^{18)}$, the Borg scale ${ }^{32)}$, and heart-rate measurements, concluding that the strained postures adopted were more harmful than the pulse rate. Similarly, several researchers ${ }^{107)}$, using the OWAS, evaluated the workers in a eucalyptus nursery in Bahia (Brazil) and concluded that the postures adopted in the tasks of preparing cuts should be corrected rapidly and those of mini-cuts, on the other hand were established as correct. In another nursery in Brazil, growing sugar cane, Messias and Okuno ${ }^{108)}$ used the OWAS and the general method known as "Ergonomic Workplace Analysis" ${ }^{\text {"109) }}$ with the help of computer tools. The results indicated that several of the postures adopted were harmful and corrective measures were proposed.

Although it may appear surprising, not only has research been done on adult agricultural workers, both male and female, but also on children working in agriculture in India. Das et al. ${ }^{110)}$ applied the OWAS, REBA ${ }^{16)}$, and the standardized Nordic questionnaire ${ }^{28)}$ together with the measurement of heart rate and blood pressure. The results showed that the parts of the body most affected in children during farm labour were the lumbar area, the knees, hands, shoulders, and neck.

For the apple harvest, other authors ${ }^{111}$ used the OWAS and selected a group of fruit pickers, both male and female, whom he also interviewed, analysing their oxygen consumption and heart rate. The results were conclusive, indicating the need to adopt short-term corrective action.

Maia and de Francisco ${ }^{112)}$ applied the OWAS together with a questionnaire on MSD in the charcoal industry. This study demonstrated that inappropriate postures performed at work caused musculoskeletal disorders.

$\mathrm{Ng}$ et al. ${ }^{113)}$ investigated the MSD in the tasks carried out by pickers of oil-palm fruit. The OWAS was used together with a questionnaire. It was demonstrated that the strained postures detected were directly related to MSD that the workers suffered.

Velasquez et al. ${ }^{114)}$ also used this method with rubber agro industry workers. They suggested some improvements as very forced back postures were detected.

Finally, Sakamoto et al. ${ }^{115)}$, did research with OWAS on postures performed by asparagus harvest workers who were using adapted scissors and others traditional ones. They showed that adapted scissors decreased the risk of suffering from musculoskeletal disorders.

\subsubsection{Livestock}

The milking of cows has been widely analysed by several authors by OWAS and other complementary parameters. For Nevala Puranen et al. ${ }^{116)}$, the work of milking was light for the musculoskeletal and cardiorespiratory system, both in males as well as in females, according not only to the OWAS but also measurements of cardiac frequency. Pinzke et al. ${ }^{117)}$ using the OWAS as well as surface electomyography, studied the time spent and the work load in milking cows that were tied up and those that were loose. Also, Perkio-Makela and Hentila ${ }^{118)}$ evaluated workers in charge of open-range cattle. They measured the workers' heart rate, the perceived effort by questionnaires and the work postures by the OWAS. The images showed that most of the tasks required strained postures for the back. Several authors ${ }^{119)}$ also analysed two dairymen during the milking of cows. The manual transport of the milk and a mechanized system were evaluated. It was deduced, surprisingly, but the use of the OWAS that the automation did not alleviate the posture load.

In poultry, Scott and Lambe ${ }^{120)}$ recorded videos of tasks carried out by workers collecting the eggs of penned chickens and concluded that the postures adopted to collect the eggs were not the most suitable, proposing corrective measures. Finally, on a chicken farm, Carvalho et al. ${ }^{36)}$ used the OWAS and the Michigan test ${ }^{27}$ ) with the help of computer evaluation tools to warn of strained postures with possible MSD consequences.

In the agriculture and livestock sector, differences can be distinguished between workers from developed countries (Finland and Sweden, mainly) and other less developed countries (e.g. Brazil and India). In the former case, better work postures are adopted and more automation is used, whereas in the latter case the situations are more precarious, and even child labour is used. This could be due to the fact that agriculture and livestock are primary-production sectors and therefore of extreme necessity.

Also, the analysis of strained postures was made in organic farming. This may be important within the concept of sustainability of any company or process, which is based on economic, ecological, and social development maintained over time $\mathrm{e}^{121)}$.

As in other fields of knowledge, the use of the OWAS is almost always complemented with other semi-direct and indirect methods (Table 1), presumably for its limitations.

\subsubsection{Information and communications}

Table 7 shows works on the implementation of software 
Table 7. Information and communications

\begin{tabular}{|c|c|c|c|c|}
\hline References & Location & Date & Objective & Section \\
\hline 122) & Finland & 1988 & Development of a computer application for the OWAS method. & 3.1 .6 \\
\hline 123) & Finland & 1992 & Development of a data collection and analysis system for the OWAS. & 3.1 .6 \\
\hline 124) & Sweden & 1997 & $\begin{array}{l}\text { Use of a PC together with a video camera to record data and make evaluations. Ergonomic evaluation } \\
\text { by the OWAS. }\end{array}$ & 3.1 .6 \\
\hline 125) & Sweden & 2001 & Development of the way to use the OWAS automatically. & 3.1 .6 \\
\hline 126) & Spain & 2007 & Use of simulation for the ergonomic analysis and evaluation of postures according to the OWAS. & 3.1 .6 \\
\hline 128) & Japan & 2008 & Use of virtual reality and posture evaluation with the OWAS. & 3.1 .6 \\
\hline 129) & Italy & 2008 & Use of simulation and modelling together with the OWAS method for the ergonomic design of a job. & 3.1 .6 \\
\hline 127) & South Korea & 2008 & Use of the OWAS to analyse postures represented by the digital human model. & 3.1 .6 \\
\hline 130) & Italy & 2009 & Development of a methodology for the ergonomic design of work places of an industry. & 3.1 .6 \\
\hline 131) & Japan & 2010 & Use of virtual reality and posture evaluation with the OWAS. & 3.1 .6 \\
\hline 134) & Sweden & 2011 & $\begin{array}{l}\text { Development of a platform for storing data and information on movements, analysed according to the } \\
\text { OWAS. }\end{array}$ & 3.1 .6 \\
\hline 132) & Japan & 2012 & $\begin{array}{l}\text { Development of a system that, with the use of virtual reality, enables the evaluation of work postures, } \\
\text { using the OWAS for their evaluation. }\end{array}$ & 3.1 .6 \\
\hline 136) & Germany & 2012 & Ergonomic evaluation with software that uses the OWAS method. & 3.1 .6 \\
\hline 133) & China & 2014 & Ergonomic simulation using the OWAS and BSHA. & 3.1 .6 \\
\hline 137) & Spain & 2014 & Development of software for the OWAS, in which data are acquired by the sensor Kinect I. & 3.1 .6 \\
\hline 35) & Turkey & 2015 & Development of the software I-OWAS. & 3.1 .6 \\
\hline 139) & Japan & 2016 & Use of Kinect sensor to evaluate postures. & 3.1 .6 \\
\hline 140) & Portugal & 2016 & Application of surface electromyography (sEMG) and 3D cameras to evaluate postures. & 3.1 .6 \\
\hline 141) & United States & 2016 & Application of computer vision to evaluate postures. & 3.1 .6 \\
\hline
\end{tabular}

tools that have been developed to use the OWAS by means of computers.

The first researchers to facilitate the analysis of images by computer applications were Vayrynen ${ }^{122)}$ and Long ${ }^{123)}$. Both succeeded in integrating the data gathering of the OWAS (photographic and video camera) together with a computer to enable its subsequent evaluation. Some years later, Engsrom and Medbo ${ }^{124)}$ did the same but provided examples of application in the automobile industry. Pinzke and Kopp ${ }^{125)}$ attempted to advance a bit more and studied the possibility of applying the OWAS automatically using computer and video techniques.

Santos et al. ${ }^{126)}$ used 3D videos (eM-Workplace) in a task of furniture manufacturing for the application of the OWAS by a digital human model in real time that also included the work area. This same model was used by several authors ${ }^{127}$ in an assembly task in the automobile industry, with the difference that in addition to the OWAS, they used RULA and REBA. Similarly, but with other computer programs of human/digital-space modelling, the OWAS was applied in industrial activities ${ }^{128-133)}$. The tool enables the subsequent evaluation to correct the worker by the mouse or keyboard.

Seeking the fastest use, Keyvani et al. ${ }^{134)}$ developed a storage system for images/data of movements using MATLAB $^{135)}$ to be subsequently analysed according to the OWAS. Klippert et al. ${ }^{136)}$ evaluated strained postures using software for the analysis according to the OWAS. These authors compared the traditional evaluation (without software) with the computerized evaluation and concluded that the work time of the operator had been optimised. Diego-Mas and Alcaide-Marzal ${ }^{137)}$ developed a software for the application of the OWAS based on a wireless sensorial/virtual computer system connected between the individual and the computer, called Kinect ${ }^{138}$. Figlali et al. ${ }^{35)}$ have developed the software tool I-OWAS that permits the analysis of images of work tasks and evaluates them at the same time.

Finally, several authors ${ }^{139-141)}$ used new technologies allowing information compilation to apply OWAS method.

The evolution from the analysis by photos, videos, digital/spatial human modelling towards Kinect ${ }^{138)}$ technology appears clear.

Although the OWAS was conceived as a semi-direct evaluation method (Table 1) the development of new technologies has enabled the OWAS to be applied as a direct method. This has also been extended to the rest of the semi-direct methods (Table 1). Also, these technologies have palliated one of the drawbacks of the method based on the factor "evaluation time". Perhaps companies have not yet developed computer systems of the latest generation that allow the control of strained postures in real time. 
Table 8. Construction

\begin{tabular}{|c|c|c|c|c|}
\hline References & Location & Date & Objective & Section \\
\hline 142) & Finland & 1991 & $\begin{array}{l}\text { Application of the OWAS in building construction, with the development of a computer application for } \\
\text { the OWAS. }\end{array}$ & 3.1 .7 \\
\hline 143) & Finland & 1993 & Application of the OWAS by computer in workers undertaking hammering tasks. & 3.1 .7 \\
\hline 145) & Taiwan & 1999 & Application of the OWAS in construction workers; design of the program CCOWAS. & 3.1 .7 \\
\hline 144) & Finland & 1999 & $\begin{array}{l}\text { Comparison of physical load caused in young workers and those of advanced age, by the OWAS and other } \\
\text { techniques. }\end{array}$ & 3.1 .7 \\
\hline 146) & Germany & 2003 & Various methods and techniques, including the OWAS are applied in workers in charge of flooring. & 3.1 .7 \\
\hline 147) & Brazil & 2006 & Application of the OWAS and other evaluation tools in suspended scaffolding. & 3.1 .7 \\
\hline 150) & China & 2009 & Application of methods including the OWAS, in workers installing electrical lines in China. & 3.1 .7 \\
\hline 148) & Portugal & 2012 & Application of the OWAS and other ergonomic tools in construction workers. & 3.1 .7 \\
\hline 149) & Taiwan & 2013 & Application of the OWAS in construction workers of the foundation of a cabin. & 3.1 .7 \\
\hline
\end{tabular}

\subsubsection{Construction}

Table 8 lists the studies related to the construction sector that have applied the OWAS.

Kivi and Mattila ${ }^{142)}$ used the OWAS with the help of computer tools in construction workers. The results identified the strained postures and facilitated the adoption of corrective measures. Also, for hammering in construction, other authors ${ }^{143}$ applied the OWAS with the help of a computer, concluding that $7.8 \%$ of the postures analysed should be urgently corrected. Afterwards, Louhevaara ${ }^{144)}$ used the OWAS to make a biomechanical comparison between male workers, young as well as advanced in age. For this the author evaluated the dynamic load, static load, and the perceived effort. The results showed that age was not an influential factor in the physical load of these workers.

In Taiwan, $\mathrm{Li}$ and Lee ${ }^{145)}$, on applying the OWAS in construction workers, with the help of computer software, discovered harmful postures that should be immediately corrected. Also, the use of other methods was necessary to evaluate the positions of the hands.

In the same way, the OWAS together with other methods was used to evaluate workers dedicated to flooring ${ }^{146)}$. The authors concluded that the most important MSD were provoked by the adoption of strained postures due to the weight of the rolls used for flooring.

Saurin and Guimaraes ${ }^{147}$ ) used the OWAS to evaluate workers on suspended scaffolding (lightweight and heavy). These authors used other methods, deducing that in both types of scaffolding the workers exceeded the thresholds of strained posture, and therefore required corrective actions.

Bolonha et al. ${ }^{148)}$ evaluated construction workers of houses, applying the OWAS and RULA. These researchers observed a high number of strained postures in different phases of execution of a dwelling, the most harmful being adopted in the execution of the foundation. Lee and $\operatorname{Han}^{149)}$ used the OWAS in the construction sector with the support of videos. These authors detected incorrect postures, notably the bent, twisted trunk.

Finally, several researchers ${ }^{150)}$ used the OWAS in workers related to the maintenance of electric lines in Chinas. In this case, strained postures were detected and corrective measures were proposed.

\subsubsection{Transportation and storage}

Table 9 represents all the studies using the OWAS in transport and storage.

Kant et al. ${ }^{151)}$, using the OWAS to evaluate auto-repair workers, recommended corrective actions.

Wright and Haslam ${ }^{152,153)}$ investigated the MSD risks in a soft-drink distribution centre, specifically in manual handling tasks. The use of the OWAS was complemented by other evaluation methods. In both studies the results showed that there are strained postures in areas of storage and delivery.

Forklift drivers ${ }^{154)}$ and drivers of commercial vehicles ${ }^{155)}$ were studied by means of the OWAS and RULA. In addition, several authors ${ }^{154)}$ analysed vibrations during the work. In both cases, the lumbar pain was related to the strained postures adopted during the tasks. Also, in the case of the forklift drivers, certain harmful vibrations were detected. Ravnik et al. ${ }^{156)}$ studying a group of automobile drivers, used the OWAS, RULA, the Corlett method, auxiliary questionnaires, and goniometry to identify the strained postures and their relation to MSD that the workers suffered. Farias et al. ${ }^{157)}$ used this approach for tasks of loading and unloading lorries with the aid of photographs and videos. In addition to using the OWAS, they used complementary evaluation methods. According to the observations, there was at least one very harmful posture that required immediate corrective actions.

$\mathrm{Li}^{158)}$, with the OWAS, evaluated toll-booth workers and 
Table 9. Transportation and Storage

\begin{tabular}{|c|c|c|c|c|}
\hline References & Location & Date & Objective & Section \\
\hline 151) & Netherlands & 1990 & Application of the OWAS in auto-repair workers. & 3.1 .8 \\
\hline 152) & England & 1998 & $\begin{array}{l}\text { Application of the OWAS and the NIOSH equation in workers handling soft drinks in a distribution } \\
\text { centre. }\end{array}$ & 3.1 .8 \\
\hline 153) & England & 1999 & Application of the OWAS and other tools in workers in a soft-drink distribution centre. & 3.1 .8 \\
\hline 154) & Scotland & 2005 & Application of the OWAS and RULA in forklift drivers. & 3.1 .8 \\
\hline 155) & Malaysia & 2007 & $\begin{array}{l}\text { Application of different techniques, such as the OWAS, to study lumbar pain in drivers of commercial } \\
\text { vehicles. }\end{array}$ & 3.1 .8 \\
\hline 156) & Slovenia & 2008 & Application of the OWAS and other techniques to analyse the discomfort of automobile drivers. & 3.1 .8 \\
\hline 157) & Brazil & 2010 & Application of the OWAS in workers who load and unload lorries. & 3.1 .8 \\
\hline 158) & Taiwan & 2010 & Application of the OWAS in toll-booth workers. & 3.1 .8 \\
\hline 159) & Italy & 2014 & Use of six methods, including the OWAS in workers who load and unload airplanes. & 3.1 .8 \\
\hline 160) & Italy & 2016 & Application of the OWAS and other tools in workers handling cargo in pallets. & 3.1 .8 \\
\hline
\end{tabular}

Table 10. Teaching

\begin{tabular}{clllc}
\hline References & Location & Date & Objective & Section \\
\hline 161$)$ & Slovenia & 2010 & Temporary Observation Method and the OWAS to investigate school work. & 3.1 .9 \\
$162)$ & Brazil & 2013 & Application of the OWAS and RULA in odontology students. & 3.1 .9 \\
$163)$ & Turkey & 2016 & Application of the OWAS and other methods in teachers. & 3.1 .9 \\
$164)$ & Belgium & 2016 & Application of the OWAS in secondary school teachers. & 3.1 .9 \\
\hline
\end{tabular}

found numerous postures to be harmful both for the workers in the booths located in the car lanes as well as those in the lorry and bus lanes. Short-term corrective actions were advised.

Cattaneo et al. ${ }^{159)}$ evaluated the tasks of loading and unloading airplanes for an airline transport company. These researchers used the OWAS, KIM, MAC, and NIOSH (Table 1) for the loading and KIM, Snook, and Ciriello (Table 1) for unloading. The results indicated that none of the methods are $100 \%$ efficient to evaluate MSD risks.

Finally, Calzavara et al. ${ }^{160)}$, used OWAS and other methods with workers handling loads (pallets).

As in other studies, the OWAS is not normally used alone when evaluating the tasks in this field of knowledge, to offset its limitations especially in the actions of loading and unloading. The OWAS is a good method to evaluate strained postures but it is not ideal for evaluating the handling of cargo and thus is combined with other methods more suitable for tasks of transport and logistics.

\subsubsection{Teaching}

Only four studies are available in this field of knowledge (Table 10).

Fosnaric and Planinsec ${ }^{161)}$ using the OWAS and the multimoment method, evaluated a group of students during the practice session of a subject. The researchers concluded that it was possible to improve the performance of the stu- dents without changing the postures adopted.

García et al. ${ }^{162)}$ applied the OWAS and RULA in odontology students. The OWAS method warned of a moderate risk while the RULA indicated very high risk. Both methods recommended corrective actions.

Apaydin et al. ${ }^{163)}$, related factors like body-mass index, age and time performing forced postures, using OWAS and suggesting correcting measures.

As well, other authors ${ }^{164)}$ applied OWAS to evaluate secondary school teachers who used electronic school boards and conventional chalkboards. In both cases, they concluded there was not an important risk of suffering from musculoskeletal disorders.

Normally, teaching professionals are exposed to psychophysical and physical tension. However, the use of the OWAS in this field has been scant. This may be because it does not involve tasks of heavy physical loads and perhaps psychosocial factors are predominant.

3.1.10. Wholesale and retail trade; motorcycles and motor vehicles reparation.

Table 11 presents the use of the OWAS in the trade field, as there is no evidence of any study about motorcycles and motor vehicles reparation.

Carrasco et al. ${ }^{165)}$ used the OWAS and other support methods to evaluate supermarket workers while they worked at the cash register. Improvement actions were rec- 
Table 11. Wholesale and retail trade; motorcycles and motor vehicles reparation

\begin{tabular}{cllll}
\hline References & Location & Date & Objective & Section \\
\hline 165$)$ & Australia & 1995 & Application of the OWAS, recordings of the heart rate and perception of effort in supermarket personnel. & 3.1 .10 \\
$166)$ & India & 2016 & Application of the OWAS and other methods in workers of a central market. & 3.1 .10 \\
\hline
\end{tabular}

Table 12. Accommodation and catering activities

\begin{tabular}{ccccc}
\hline References & Location & Date & Objective & Section \\
\hline 167$)$ & China & 2014 & Application of the OWAS, RULA, and NIOSH in Chinese restaurant cooks. & 3.1 .11 \\
\hline
\end{tabular}

Table 13. Administrative and support services activities

\begin{tabular}{ccccc}
\hline References & Location & Date & Objective & Section \\
\hline 168$)$ & Taiwan & 2016 & Application of the OWAS in a University cleaning staff. & 3.1 .12 \\
\hline
\end{tabular}

ommended.

Sarkar et al. ${ }^{166)}$ used it to evaluated postures performed by workers handling goods in a central market. The concluded that $83 \%$ of the postures were injuring and should be urgently corrected. As well, they used the Standardized Nordic Questionnaire ${ }^{28)}$ to measure the frequency of these workers suffering from musculoskeletal disorders.

\subsubsection{Accommodation and catering activities}

Table 12 includes only one activity in this field.

$\mathrm{Xu}$ and Cheng ${ }^{167)}$ using the OWAS, RULA, and the NIOSH equation to evaluate restaurant cooks in Hong Kong, warned of very repetitive tasks and recommended corrective measures.

\subsubsection{Administrative and support services activities}

Table 13 also includes only one study referring this field. Several authors ${ }^{168)}$ applied OWAS method to evaluate postures of workers performing cleaning activities in the university. Forced postured were detected and the adaptation or modifications of cleaning tools was recommended.

\subsection{By country}

For each study presented above, the countries of origin of the authors were considered (Fig. 3).

In total, the OWAS was applied in 125 studies, and the country with the highest number of works was Finland, with a total of 13, followed by Brazil with 12, Netherlands with 10, India and United Kingdom with 8, Slovenia with 7, Poland, Japan, Italy, and Germany with 6, Taiwan and Turkey with 5, Sweden and USA with 4, China, South Korea, Portugal, and Spain with 3, Iran, Malaysia, and Australia with 2, and Austria, Canada, Cuba, Indonesia,
Colombia, Belgium and Thailand with one each (Fig. 3).

Figure 4 presents the studies made by field of knowledge in each country. Of these the country that has most applied the OWAS in different sectors is Brazil, with 6, followed by Finland with 5; Germany, Slovenia, India, Italy Netherlands, Taiwan, Turkey, and United Kingdom with 4; China, Portugal and Poland with 3; Australia, South Korea, Spain, Malaysia, Sweden, and USA with 2; and Belgium, Colombia, Iran, Thailand, Indonesia, Cuba, Canada, and Austria with one.

It is not surprising that the country with the most studies applying the OWAS was Finland, since this is the country of origin of the authors of method. In this country, the OWAS has been applied in almost all the sectors, particularly "agriculture, livestock, forestry, and fishing" with 4 and "construction" and "manufacturing industries" with 3 studies published. A similar case in the sector "agriculture, livestock, forestry, and fishing" occurs in Brazil, with 5 studies. In turn, India is notable with 5 studies in the last $6 \mathrm{yr}$ of a total of 8 in the "manufacturing industries" field, perhaps for being an emerging economy.

In the Netherlands, of a total of 10 studies, half were conducted in the sector of "healthcare and social assistance activities". Similarly in Poland, of a total of 6 studies, 4 were in the "healthcare and social assistance activities area".

In the category of information and communications, Japan stand out with 4 studies. This country has economy associated with new technologies.

Finally, United Kingdom focus it investigations on the transportation and storage field, and in the healthcare and social assistance activities with 3 each one, out of a total of 8 . 


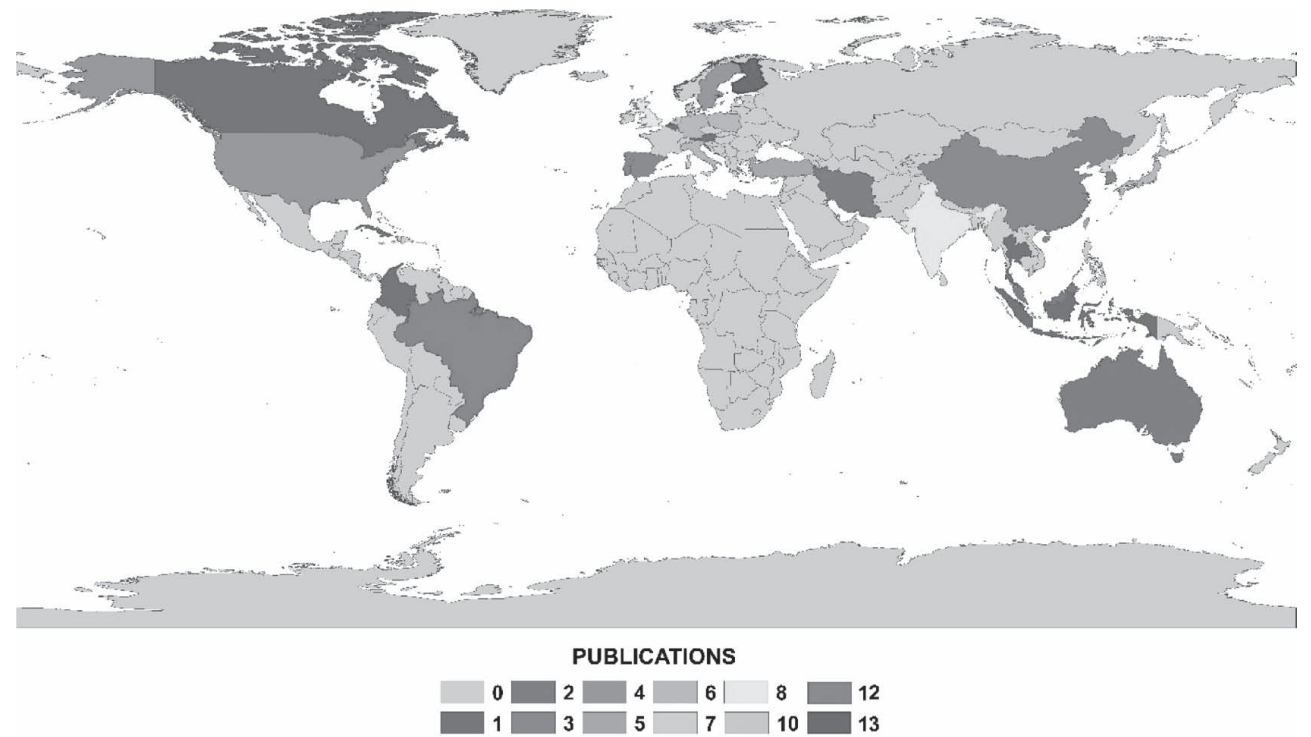

Fig. 3. Publications by country.

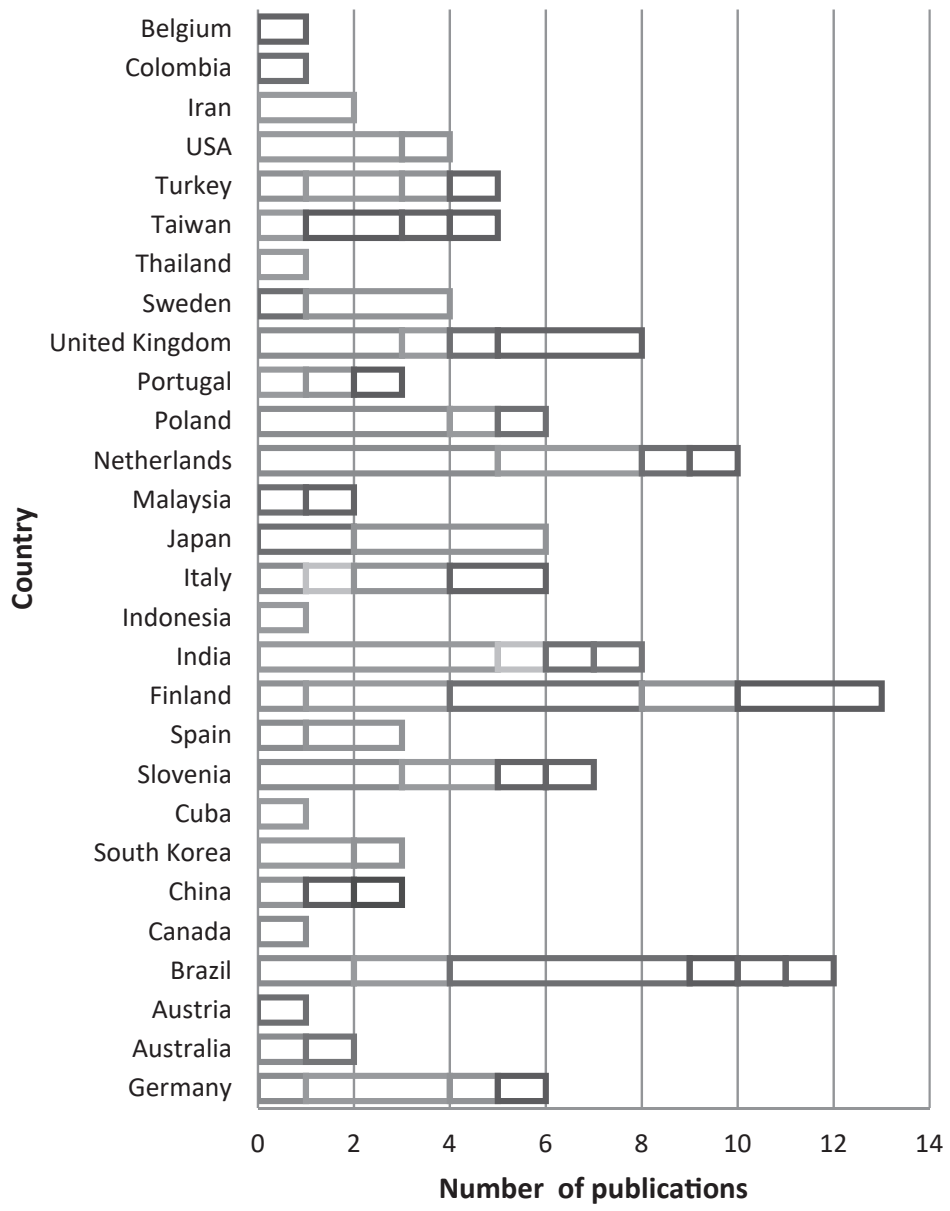

- Healthcare and social assistance activities

- Housework activities as employers; non differed housework activities as good and services producers for their own use - Manufacturing industries

Mining and quarrying

- Agriculture, livestock, forestry, and fishing

- Information and communications

- Construction

- Transportation and storage

- Teaching

Wholesale and retail trade; motorcycles and motor vehicles reparation

-Accommodation and catering activitie

- Administrative and support services activities

Fig. 4. Number of publications in each field of knowledge by country. 


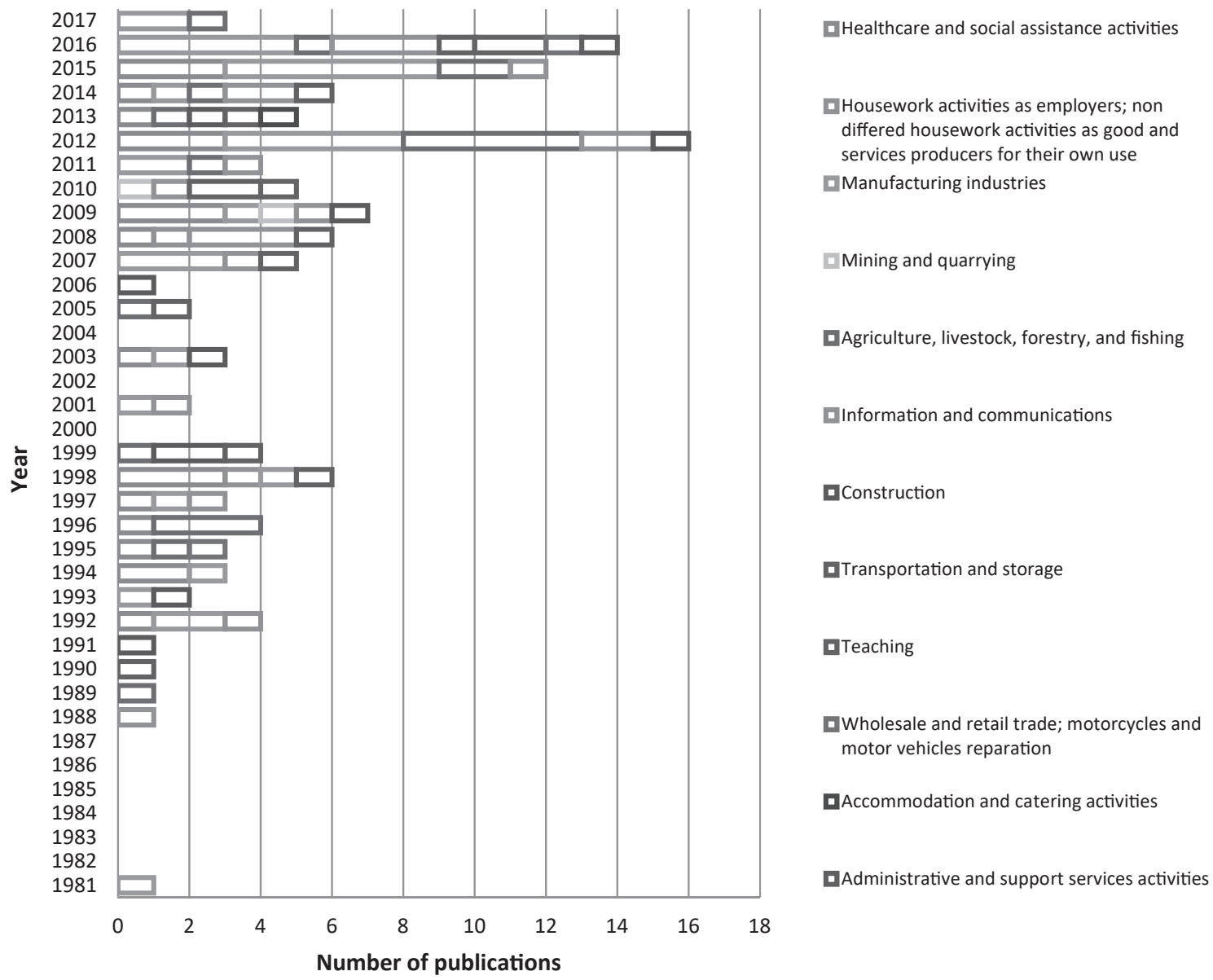

Fig. 5. Number of publications in each field of knowledge by year.

\subsection{By year}

Figure 5 shows the number of publications by year as well as by the number of fields studied each year.

The year having the greatest number of publications was 2012, with 16 publications in 5 fields of knowledge, followed by 2016 with 14 publications in 7 fields of knowledge. On the contrary, for the years 1981, 1988, 1989, 1990, 1991, 2006 only one study published. Furthermore, there is a total $9 \mathrm{yr}(1982,1983,1984,1985,1986,1987$, 2000,2002 , and 2004) with no evidence of the application of the OWAS. Finally, the last $10 \mathrm{yr}$ account for the greatest number of works.

Because of the massive access to Internet worldwide, the dissemination of scientific studies has grown exponentially with respect to the 1980 s, especially in the last $10 \mathrm{yr}$. This fact has influenced the greater application of the OWAS in recent years. In addition, the technological development mixed with mathematical methodologies of optimising processes have encouraged the appearance of new computer tools to greatly facilitate the use of semi- direct methods (Table 1).

In the future, research may continue with this method, not only in the fields of knowledge analysed here but also in others still to be explored (sports activities, recreation, artistic endeavours, entertainment, hotels, aviation, etc.).

\section{Conclusions}

The OWAS has been applied mainly in three sectors: industry, health, and agriculture and livestock. It is one of the most widely used and tested semi-direct methods of MSD evaluation in the world, but needs to be complemented with other indirect or direct methods.

The application of the OWAS has been digitalized/computerized, based on the development of new technologies of information and communication, which has greatly shortened the application time since its appearance.

The forced postures detected by OWAS will depend on the physical conditions and the perception and interpretations of the tasks made by the workers in the different 
working environments.

Finally, whenever the OWAS has been used, whether individually or together with other methods, MSD risks have been detected, this perhaps being an indicator to review the evaluation parameters because overestimating the risk.

\section{Acknowledgements}

University Research Contracts Numbers 401090, 401250 and 401251 funded this study. Also to LaboratoryObservatory Andalusian Working Conditions in the Agricultural Sector (LASA) and to Research Plan of the University of Almería.

\section{References}

1) EU-OSHA (European Agency for Safety and Health at Work). Prevención de los trastornos musculoesqueléticos de origen laboral 2000. https://osha.europa.eu/es/toolsand-publications/publications/factsheets/4. Accessed May 20, 2016.

2) EU-OSHA (European Agency for Safety and Health at Work). Introducción a los trastornos musculoesqueléticos de origen laboral 2007. https://osha.europa.eu/es/toolsand-publications/publications/factsheets/71. Accessed May 20, 2016.

3) EU-OSHA (European Agency for Safety and Health at Work). OSH in figures: Work-related musculoskeletal disorders in the EU-Facts and figures 2010. Edited by European Agency for Safety and Health at Work (EUOSHA). European Risk Observatory Report, 11-26, Luxembourg. https://osha.europa.eu/es/tools-and-publications/ publications/reports/TERO09009ENC. Accessed May 20, 2016.

4) Miranda H, Kaila-Kangas L, Ahola K (2011) Ache and Melancholy- Co-occurrence of musculoskeletal pain and depressive symptoms in Finland. Edited by Finnish Institute of Occupational Health. Ministry of Social Affairs and Health. Finland. 5pp.

5) OSHA (Occupational Safety \& Health Administration) (2016) https://www.osha.gov/SLTC/ergonomics/. Accessed May 23, 2016.

6) CCOHS (Canadian Centre for Occupational Health and Safety) (2009) http://www.labour.gov.on.ca/english/hs/ pubs/pains/index.php. Accessed May 23, 2016.

7) Luttmann A, Jäger M, Griefahn B (2004) Prevención de trastornos musculoesqueléticos en el lugar de trabajo. Serie de protección de la salud de los trabajadores 5, 1 . http://www.who.int/occupational_health/publications/en/ pwh5sp.pdf?ua =1. Accessed May 20, 2016.

8) ILO (International Labour Organization) (2013) http:// www.ilo.org/wcmsp5/groups/public/---ed protect/-- -protrav/---safework/documents/presentation/wcms 232617.pdf. Accessed May 23, 2016.

9) Llaneza-Álvarez FJ (2008) Ergonomía y Psicosociología aplicada. Manual para la formación del especialista, 10th Ed., 295, Lex Nova, Spain.

10) McAtamney L, Nigel Corlett E (1993) RULA: a survey method for the investigation of work-related upper limb disorders. Appl Ergon 24, 91-9 (doi:10.1016/0003-6870 (93)90080-S). [Medline] [CrossRef]

11) Moore JS, Garg A (1995) The Strain Index: a proposed method to analyze jobs for risk of distal upper extremity disorders. Am Ind Hyg Assoc J 56, 443-58. [Medline] [CrossRef]

12) James CPA, Harburn KL, Kramer JF (1997) Cumulative trauma disorders in the upper extremities: reliability of the postural and repetitive risk-factors index. Arch Phys Med Rehabil 78, 860-6 (doi:10.1016/S0003-9993(97)90201$\mathrm{X})$. [Medline] [CrossRef]

13) García C, Chirivela C, Page del Pozo A, Moraga R, Jorquera J (1997) Método Ergo IBV. Evaluación de riesgos laborales asociados a la carga física. Instituto de Biomecánica de Valencia (IBV), Valencia, España.

14) Colombini D (1998) An observational method for classifying exposure to repetitive movements of the upper limbs. Ergonomics 41, 1261-89 (doi:10.1080/001401398186 306). [Medline] [CrossRef]

15) Kemmlert K (1995) A method assigned for the identification of ergonomic hazards - PLIBEL. Appl Ergon 26, 199-211 (doi:10.1016/0003-6870(95)00022-5). [Medline] [CrossRef]

16) Hignett S, McAtamney L (2000) Rapid entire body assessment (REBA). Appl Ergon 31, 201-5 (doi:10.1016/S00036870(99)00039-3). [Medline] [CrossRef]

17) Karhu O, Kansi P, Kuorinka I (1977) Correcting working postures in industry: A practical method for analysis. Appl Ergon 8, 199-201 (doi:10.1016/0003-6870(77)90164-8). [Medline] [CrossRef]

18) Corlett E, Madeley S, Manenica I (1979) Posture targetting: a technique for recording working postures. Ergonomics 22, 357-66 (doi:10.1080/00140137908924619). [CrossRef]

19) Kilbom A, Persson J, Jonsson B (1986) Risk factors for work-related disorders of the neck and shoulder - with special emphasis on working postures and movements. In: E.N. Corlett, J. Wilson and I. Manenica eds. The ergonomics of working postures, 44-53, Taylor \& Francis, London.

20) Buchholz B, Paquet V, Punnett L, Lee D, Moir S (1996) PATH: a work sampling-based approach to ergonomic job analysis for construction and other non-repetitive work. Appl Ergon 27, 177-87 (doi:10.1016/0003-6870(95) 00078-X). [Medline] [CrossRef]

21) INSHT (Instituto Nacional de Seguridad e Higiene en el Trabajo) (1998) Guía técnica para la evaluación y prevención de los riesgos relativos a la manipulación manual de cargas. Guías técnicas. Madrid, España. 
22) NIOSH (National Institute for Occupational Safety and Health) (1981). Work practices guide for manual lifting. NIOSH Technical Report $n^{\circ} 81-122$, Cincinnaty, Ohio, USA.

23) Snook SH, Ciriello VM (1991) The design of manual handling tasks: revised tables of maximum acceptable weights and forces. Ergonomics 34, 1197-213 (doi:10.1080/0014 0139108964855). [Medline] [CrossRef]

24) Jürgens WW, Mohr D, Pangert R, Pernack E, Schultz K, Steinberg U (2001). Handlungsanleitung zur Beurteilung der Arbeitsbedingungen beim Heben und Tragen von Lasten. LASI Veröffentlichung 9. Hrsg. Länderausschuss für Arbeitsschutz und Sicherheitstechnik. 4. Überarbeitete Auflage.

25) Monnington S, Quarrie C, Pinder A, Morris L (2003) Development of Manual Handling Assessment Charts (MAC) for health and safety inspectors. In: Contemporary Ergonomics, Taylor \& Francis, London.

26) Liberty-Mutual. Manual Materials Handling Tables 2011. http://libertymmhtables.libertymutual.com/CM_LM TablesWeb/pdf/LibertyMutualTables.pdf. Accessed Jan 22, 2014.

27) Lifshitz Y, Armstrong T (1986) A design checklist for control and prediction of cumulative trauma disorders in hand intensive manual jobs. In: Proceedings of the 30th Annual Meeting of Human Factors Society, 837-41, Michigan.

28) Kuorinka I, Jonsson B, Kilbom A, Vinterberg H, BieringSørensen F, Andersson G, Jørgensen K (1987) Standardised Nordic questionnaires for the analysis of musculoskeletal symptoms. Appl Ergon 18, 233-7 (doi: 10.1016/0003-6870(87)90010-x). [Medline] [CrossRef]

29) Keyserling WM, Brouwer M, Silverstein BA (1992) A checklist for evaluating ergonomics risk factors resulting from awkward postures of the legs, trunk and neck. Int J Ind Ergon 9, 283-301 (doi:10.1016/0169-8141(92)900625). [CrossRef]

30) Keyserling WM, Stetson DS, Silverstein BA, Brouwer ML (1993) A checklist for evaluating ergonomic risk factors associated with upper extremity cumulative trauma disorders. Ergonomics 36, 807-31 (doi:10.1080/00140139308 967945). [Medline] [CrossRef]

31) David G, Woods V, Li G, Buckle P (2008) The development of the Quick Exposure Check (QEC) for assessing exposure to risk factors for work-related musculoskeletal disorders. Appl Ergon 39, 57-69 (doi:10.1016/j. apergo.2007.03.002). [Medline] [CrossRef]

32) Borg G (1970) Perceived exertion as an indicator of somatic stress. Scand J Rehabil Med 2, 92-8. [Medline]

33) Takala EP, Pehkonen I, Forsman M, Hansson GA, Mathiassen SE, Neumann WP, Sjøgaard G, Veiersted KB, Westgaard RH, Winkel J (2010) Systematic evaluation of observational methods assessing biomechanical exposures at work. Scand J Work Environ Health 36, 3-24 (doi:10.5271/sjweh.2876). [Medline] [CrossRef]

34) INERMAP (Instituto de Ergonomía) (2011) Ergomet
3.0. http://www.inermap.com/software/ergomet.html. Accessed Feb 20, 2017.

35) Figlali N, Cihan A, Esen H, Figlali A, Cesmeci D, Gullu MK, Yilmaz MK (2015) Image processing-aided working posture analysis: I-OWAS. Comput Ind Eng 85, 384-94 (doi:10.1016/j.cie.2015.03.011). [CrossRef]

36) Carvalho CCS, Souza CD, Tinoco IDF, Santos LV, Minette LJ, da Silva EP (2015) Activities and ergonomics of workers in broiler hatcheries. Rev. Bras. Cienc. Avic. 17, $123-$ 36. (doi:10.1590/1516-635x1702123-136). [CrossRef]

37) Wahyudi MA, Dania WAP, Silalahi RLR (2015) Work posture analysis of manual material handling using OWAS method. In: International Conference on Agro-Industry Competitive and Sustainable Agro-Industry for Human Welfare (IcoA), 195-9, Yogyakarta, Indonesia. [CrossRef]

38) Li G, Buckle P (1999) Current techniques for assessing physical exposure to work-related musculoskeletal risks, with emphasis on posture-based methods. Ergonomics 42, 674-95 (doi:10.1080/001401399185388). [Medline] [CrossRef]

39) Valero E, Sivanathan A, Bosché F, Abdel-Wahab M (2016) Musculoskeletal disorders in construction: A review and a novel system for activity tracking with body area network. Appl Ergon 54, 120-30 (doi:10.1016/j.apergo.2015. 11.020). [Medline] [CrossRef]

40) Roman-Liu D (2014) Comparison of concepts in easy-touse methods for MSD risk assessment. Appl Ergon 45, 420-7 (doi:10.1016/j.apergo.2013.05.010). [Medline] [CrossRef]

41) Wos (Web of Science) (2016) Foundation for Science and Technology (FECYT). Library of the University of Almería, Almería, Spain.

42) UNO (United Nations Organization) (2009) Clasificación Industrial Internacional Uniforme de todas las actividades económicas (CIIU). Departamento de Asuntos Económicos y Sociales. División de Estadística. Informes estadísticos. Serie M, No.4/Rev.4. Nueva York. USA [In Spanish]. https://unstats.un.org/unsd/publication/SeriesM/ seriesm 4rev4s.pdf. Accessed March 25, 2017.

43) Kant IJ, de Jong LCGM, van Rijssen-Moll M, Borm PJA (1992) A survey of static and dynamic work postures of operating room staff. Int Arch Occup Environ Health 63, 423-8 (doi:10.1007/BF00386939). [Medline] [CrossRef]

44) Kułagowska E (2008) [The musculoskeletal system load during work performed by nurse anesthetists]. Med Pr 59, 287-92. [Medline]

45) Kułagowska E (2009) [Musculoskeletal system load in operating room nurses and its determinants]. Med $\operatorname{Pr} 6 \mathbf{6 0}$, 187-95. [Medline]

46) Lauer W, Ibach B, Radermacher K (2009) Knowledgebased OR table positioning assistant for orthopedic surgery. In: 4th European Conference of the International Federation for Medical and Biological Engineering (ECIFMBE), 1676-8, Antwerp, Belgium. [CrossRef] 
47) Bartnicka J (2015) Knowledge-based ergonomic assessment of working conditions in surgical ward - A case study. Saf Sci 71, 178-88 (doi:10.1016/j.ssci.2014. 08.010). [CrossRef]

48) Herzog NV, Beharic RV, Beharic A, Buchmeister B (2015) Ergonomic analysis and simulation in department of ophthalmology. In: 6th International Conference on Applied Human Factors and Ergonomics (AHFE), 128-35, Las Vegas, Nevada. [CrossRef]

49) Engels JA, Landeweerd JA, Kant Y (1994) An OWASbased analysis of nurses' working postures. Ergonomics 37, 909-19 (doi:10.1080/00140139408963700). [Medline] [CrossRef]

50) Hignett S (1994) Using computerized OWAS for postural analysis of nursing work. In: Ergonomics-Societys 1994 Annual Conference-Contemporary Ergonomics 1994: Ergonomics for All, 253-8, Coventry, England.

51) Hignett $S$ (1996) Postural analysis of nursing work. Appl Ergon 27, 171-6 (doi:10.1016/0003-6870(96)00005-1). [Medline] [CrossRef]

52) Best M (1997) An evaluation of Manutention training in preventing back strain and resultant injuries in nurses. In: Occupational Injury Symposium, 207-22, Sydney, Australia. [CrossRef]

53) Engels JA, van der Gulden JWJ, Senden TF, Kolk JJ, Binkhorst RA (1998) The effects of an ergonomic-educational course. Postural load, perceived physical exertion, and biomechanical errors in nursing. Int Arch Occup Environ Health 71, 336-42 (doi:10.1007/s004200050289). [Medline] [CrossRef]

54) de Bruijn I, Engels JA, van der Gulden JWJ (1998) A simple method to evaluate the reliability of OWAS observations. Appl Ergon 29, 281-3 (doi:10.1016/S00036870(97)00051-3). [Medline] [CrossRef]

55) Stricevic J, Balantic Z, Turk Z, Celan D (2009) Ergonomic analysis of workload diminution by the use of assistive technical equipment at nursing care. Healthmed 3, 212-8.

56) Nowotny-Czupryna O, Naworska B, Brzęk A, Nowotny J, Famuła A, Kmita B, Bąk K (2012) Professional experience and ergonomic aspects of midwives' work. Int J Occup Med Environ Health 25, 265-74 (doi:10.2478/S13382012-0034-6). [Medline] [CrossRef]

57) Herzog NV, Beharic RV, Beharic A, Buchmeister B (2014) Ergonomic analysis of ophthalmic nurse workplace using 3D simulation. Int $\mathrm{J}$ Simul Model 13, 409-18 (doi:10.2507/IJSIMM13(4)2.265). [CrossRef]

58) Crawford JO, Lane RM (1998) Posture analysis and manual handling in nursery professionals. In: Annual Conference of the Ergonomics-Society Royal-Agricultural-College, 101-5, Cirencester, England.

59) Moreira HSB, Moreira MB, Vilagra JM, Galvão IM, de Oliveira Júnior AS, de Lima AC (2012) Analysis of the compensatory postures adopted by day caregivers through OWAS-Ovako Working Posture Analysing System. Work 41 Suppl 1, 5746-8 (doi:10.3233/WOR-2012-0939-
5746). [Medline] [CrossRef]

60) Doormaal MTAJ, Driessen APA, Landeweerd JA, Drost MR (1995) Physical workload of ambulance assistants. Ergonomics 38, 361-76 (doi:10.1080/0014013950892511 $0)$. [Medline] [CrossRef]

61) White HA, Lee Kirby R (2003) Folding and unfolding manual wheelchairs: an ergonomic evaluation of healthcare workers. Appl Ergon 34, 571-9 (doi:10.1016/S00036870(03)00079-6). [Medline] [CrossRef]

62) Pais FL, Azevedo PR, Medeiros LHD, de Freitas IB, Stamato C (2012) Ergonomic assessment among radiology technologists: a survey in a hospital. Work 41 Suppl 1, 1821-7 (doi:10.3233/WOR-2012-0641-1821). [Medline] [CrossRef]

63) Diniz-Baptista F (2013) Postural changes and musculoskeletal disorders in workers with mental disabilities. In: 9th International Symposium on Occupational Safety and Hygiene (SHO), 53-6, Guimaraes, Portugal. [CrossRef]

64) Marano A, Di Nicolantonio M (2015) Ergonomic design in eHealthcare: a study case of eHealth technology system. In: 6th International Conference on Applied Human Factors and Ergonomics (AHFE), 272-9, Las Vegas, Nevada. [CrossRef]

65) Pohjonen T, Punakallio A, Louhevaara V (1998) Participatory ergonomics for reducing load and strain in home care work. Int J Ind Ergon 21, 345-52 (doi:10.1016/S01698141(96)00083-2). [CrossRef]

66) Tonga E, Duger T (2008) Factors affecting low back pain in mothers who have disabled children. J Back Musculoskeletal Rehabil 21, 219-26. [CrossRef]

67) Karhu O, Härkönen R, Sorvali P, Vepsäläinen P (1981) Observing working postures in industry: Examples of OWAS application. Appl Ergon 12, 13-7 (doi:10.1016/ 0003-6870(81)90088-0). [Medline] [CrossRef]

68) Burdorf A, Derksen J, Naaktgeboren B, van Riel M (1992) Measurement of trunk bending during work by direct observation and continuous measurement. Appl Ergon 23, 263-7 (doi:10.1016/0003-6870(92)90154-N). [Medline] [CrossRef]

69) Horvat J, Polajnar I, Cudina M, Gosnak-Dahmane R (2007) Ergonomic Stresses of Welders. Strojarstvo 49, 377-82.

70) Mattila M, Vilkki M, Tiilikainen I (1992) A computerized OWAS analysis of work postures in the paper-mill industry. In: International conf on computer-aided ergonomics and safety 92-(CAES 92), 365-72, Tampere, Finland.

71) Burdorf A, van Duuren L (1993) An evaluation of ergonomic improvements in the woodworking industry. Ann Occup Hyg 37, 615-22 (doi:10.1093/annhyg/37.6.615). [Medline] [CrossRef]

72) Gilkey DP, Keefe TJ, Bigelow PL, Herron RE, Duvall K, Hautaluoma JE, Rosecrance JS, Sesek R (2007) Low back pain among residential carpenters: ergonomic evaluation using OWAS and 2D compression estimation. Int J Occup Saf Ergon 13, 305-21. [Medline] [CrossRef] 
73) Hussain A, Case K, Marshall R, Summerskill S (2016) Using ergonomic risk assessment methods for designing inclusive work practices: a case study. Hum Factors Ergon Manuf Serv Ind 26, 337-55 (doi:10.1002/hfm.20650). [CrossRef]

74) Vayrynen S, Pekkarinen A, Tornberg V (1994) Some links between accidents, postural load and accessibility in chemical-plant maintenance. Saf Sci 18, 125-33 (doi: 10.1016/0925-7535(94)90021-3). [CrossRef]

75) Vedder J (1998) Identifying postural hazards with a videobased occurrence sampling method. In: 1st International Cyberspace Conference on Ergonomics (CybErg 1996), 373-80, Electr Network. [CrossRef]

76) Sanjog J, Patel T, Chowdhury A, Karmakar S (2015) Musculoskeletal ailments in Indian injection-molded plastic furniture manufacturing shop-floor: Mediating role of work shift duration. Int $\mathrm{J}$ Ind Ergon 48, 89-98 (doi:10.1016/j.ergon.2015.04.004). [CrossRef]

77) Evangelista WL, de Fátima Tinoco I, de Souza AP, Minette LJ, da Costa Baeta F, da Silva EP, de Oliveira LA (2012) Postural analysis of workers in a typical meat processing company in Brazil. Work 41 Suppl 1, 5392-4 (doi: 10.3233/WOR-2012-0829-5392). [Medline] [CrossRef]

78) Evangelista WL, Borges LJA (2015) Application of OWAS method in the cutting sector of typical pig industry frigorific in Brazil. In: International Symposium on Occupational Safety and Hygiene (SHO), 103-5, Guimaraes, Portugal.

79) Rai A, Gandhi S, Sharma DK (2012) Ergonomic evaluation of conventional and improved methods of aonla pricking with women workers. Work 41 Suppl 1, 1239-45 (doi:10.3233/WOR-2012-0309-1239). [Medline] [CrossRef]

80) Rai A, Gandhi S, Kumar N, Sharma DK, Garg MK (2012) Ergonomic intervention in aonla pricking operation during preserve preparation in food processing industries. Work 41 Suppl 1, 401-5 (doi:10.3233/WOR-2012-0190-401). [Medline] [CrossRef]

81) Sett M, Sahu S (2012) Study on work load and workrelated musculoskeletal disorders amongst male jute mill workers of West Bengal, India. Work 42, 289-97 (doi:10.3233/WOR-2012-1352). [Medline] [CrossRef]

82) Naeini HS, Salehi N, Naeini MS (2016) An ergonomic cart design for occupational health promotion at a food manufacturing company in Iran: an approach on industrial ergonomics intervention. In: 12th International Symposium on Occupational Safety and Hygiene of Portuguese-Societyof-Occupational-Safety-and-Hygiene (SHO), 218-20, Guimaraes, Portugal.

83) Polajnar A, Caks N (2003) Scientific design of workplace for engineering in sewing process. Tekstil 52, 151-9.

84) Durlov S, Chakrabarty S, Chatterjee A, Das T, Dev S, Gangopadhyay S, Haldar P, Maity SG, Sarkar K, Sahu S (2014) Prevalence of low back pain among handloom weavers in West Bengal, India. Int J Occup Environ Health
20, 333-9 (doi:10.1179/2049396714Y.0000000082). [Medline] [CrossRef]

85) Esen H, Hatipoglu T, Figlali N (2015) Analysis of working postures in tire production sector by OWAS method. In: World Congress on Engineering (WCE 2015), 726-30, London, England.

86) Esen H, Hatipoğlu T, Fiğlali N (2016) Using OWAS in automotive subsidiary sector: a case study. In: World Congress on Engineering (WCE), 249-55, London, England. [CrossRef]

87) Lasota AM, Hankiewicz K (2016) Working postures of spot welding machine operators. In: 12th International Symposium on Occupational Safety and Hygiene of Portuguese-Society-of-Occupational-Safety-and-Hygiene (SHO), 261-4, Guimaraes, Portugal. [CrossRef]

88) Brandl C, Mertens A, Schlick CM (2017) Ergonomic analysis of working postures using OWAS in semi-trailer assembly, applying an individual sampling strategy. Int $\mathbf{J}$ Occup Saf Ergon 23, 110-7 (doi:10.1080/10803548.2016. 1191224). [Medline] [CrossRef]

89) van Wendel de Joode B, Burdorf A, Verspuy C (1997) Physical load in ship maintenance: hazard evaluation by means of a workplace survey. Appl Ergon 28, 213-9. [Medline] [CrossRef]

90) Olendorf MR, Drury CG (2001) Postural discomfort and perceived exertion in standardized box-holding postures. Ergonomics 44, 1341-67 (doi:10.1080/001401301100853 58). [Medline] [CrossRef]

91) Kee D, Karwowski W (2007) A comparison of three observational techniques for assessing postural loads in industry. Int J Occup Saf Ergon 13, 3-14. [Medline] [CrossRef]

92) Park W, Singh DP, Levy MS, Jung ES (2009) Obesity effect on perceived postural stress during static posture maintenance tasks. Ergonomics 52, 1169-82 (doi:10.1080/ 00140130902971908). [Medline] [CrossRef]

93) Kee D, Chung MK, Kim JH (2011) Legal system and its effect for prevention of work-related musculoskeletal disorders in Korea. Int J Ind Ergon 41, 224-32 (doi:10.1016/j. ergon.2011.02.001). [CrossRef]

94) Torres Y, Rodríguez Y, Viña S (2011) Preventing workrelated musculoskeletal disorders in Cuba, an industrially developing country. Work 38, 301-6 (doi:10.3233/WOR2011-1133). [Medline] [CrossRef]

95) Lu JM, Twu LJ, Wang MJJ (2016) Risk assessments of work-related musculoskeletal disorders among the TFTLCD manufacturing operators. Int J Ind Ergon 52, 40-51 (doi:10.1016/j.ergon.2015.08.004). [CrossRef]

96) Wintachai P, Charoenchai N (2012) The comparison of ergonomics postures assessment methods in rubber sheet production. In: IEEE International Conference on Industrial Engineering and Engineering Management (IEEM), 1257-61, Hong Kong. [CrossRef]

97) Ferreira C, Vaz M, Pinho ME (2015) WRMSD risk analysis in electrical and electronic equipmets' dismantling. In: International Symposium on Occupational Safety and 
Hygiene (SHO), 106-8, Guimaraes, Portugal.

98) Di Valentin C, Emrich A, Werth D, Loos P (2015) Usercentric workflow ergonomics in industrial environments concept and architecture of an assistance system. In: International Conference on Computational Science and Computational Intelligence (CSCI), 754-9, Las Vegas, Nevada. [CrossRef]

99) Yousefi HA, Habibi E, Tanaka H (2017) Prevalence of work related musculoskeletal disorders among the Iranian working population in different sectors of industries. In: 7th International Conference on Applied Human Factors and Ergonomics (AHFE)/ International Conference on Social and Occupational Ergonomics, 271-81, Bay Lake, Florida. [CrossRef]

100) Grecchi A, Cristofolini A, Correzzola C, Piccioni A, Buffa C, Pol G (2009) [Ergonomic assessment of technical improvements in the work of manual labourers of a porphyry quarry]. Med Lav 100, 142-50. [Medline]

101) Gangopadhyay S, Das B, Das T, Ghoshal G, Ghosh T (2010) An ergonomics study on posture-related discomfort and occupational-related disorders among stonecutters of West Bengal, India. Int J Occup Saf Ergon 16, 69-79. [Medline] [CrossRef]

102) Vanderschilden M (1989) The OWAS system for analyzing working postures. In: 11th workshop on labour and labour management, 129-36, Wageningen, Netherlands.

103) Nevala-Puranen N (1995) Reduction of farmers' postural load during occupationally oriented medical rehabilitation. Appl Ergon 26, 411 - 5 (doi:10.1016/0003-6870(95)000275). [Medline] [CrossRef]

104) Nevala-Puranen N (1996) Effects of occupationally-oriented rehabilitation on farmers' work techniques, musculoskeletal symptoms, and work ability. J Occup Rehabil 6, 191-200 (doi:10.1007/BF02110755). [Medline] [CrossRef]

105) Nwe YY, Toyama S, Akagawa M, Yamada M, Sotta K, Tanzawa T, Kikuchi C, Ogiwara I (2012) Workload assessment with Ovako Working Posture Analysis System (OWAS) in Japanese vineyards with focus on pruning and berry thinning operations. J Jpn Soc Hortic Sci 81, 320-6. [CrossRef]

106) Abrahão RF, Ribeiro IAV, Tereso MJA (2012) Workload composition of the organic horticulture. Work 41 Suppl 1, 5355-60 (doi:10.3233/WOR-2012-0818-5355). [Medline] [CrossRef]

107) Cunha EGS, de Souza AP, Minette LJ (2012) Ergonomic evaluation of the preparation of cuttings and minicuttings for eucalyptus seedling production, with the use of scissors. Work 41 Suppl 1, 5511-5 (doi:10.3233/WOR-20120866-5511). [Medline] [CrossRef]

108) de Anchieta Messias I, Okuno E (2012) Study of postures in sugarcane cutters in the Pontal of Paranapanema-SP, Brazil. Work 41 Suppl 1, 5389-91 (doi:10.3233/WOR2012-0828-5389). [Medline] [CrossRef]

109) FIOH (1989) Ergonomic Workplace Analysis (EWA).
Finnish Institute of Occupational Health, 32, Helsinki, Finland.

110) Das B, Ghosh T, Gangopadhyay S (2013) Child work in agriculture in West Bengal, India: assessment of musculoskeletal disorders and occupational health problems. J Occup Health 55, 244-58. [Medline] [CrossRef]

111) Callea P, Zimbalatti G, Quendler E, Nimmerichter A, Bachl N, Bernardi B, Smorto D, Benalia S (2014) Occupational illnesses related to physical strains in apple harvesting. Ann Agric Environ Med 21, 407-11 (doi:10.5604/ 1232-1966.1108614). [Medline] [CrossRef]

112) Maia IMO, Francisco AC (2012) Workers' postural conditions in the charcoal production proccess based on vertical metallic cylynders. Work 41 Suppl 1, 453-61 (doi:10. 3233/WOR-2012-0196-453). [Medline] [CrossRef]

113) Ng YG, Mohd Tamrin SB, Mohd Yusoff IS, Hashim Z, Deros BMD, Abu Bakar S, How V (2015) Risk factors of musculoskeletal disorders among oil palm fruit harvesters during early harvesting stage. Ann Agric Environ Med 22, 286-92 (doi:10.5604/12321966.1152101). [Medline] [CrossRef]

114) Velasquez S, Valderrama S, Guiraldo D (2016) Ergonomic assessment of natural rubber processing in plantations and small enterprises. Ingeniería y Competitividad 18, $233-$ 46.

115) Sakmoto T, Ochi M, Kikuchi Y, Kobayashi K, Tanaka T, Ozaki Y (2017) Reducing burden during summer asparagus (asparagus officinalis L.) spear harvest by using longshafted shears and a large-wheeled cart under modified branch training. Hortic J 86, 37-44 (doi:10.2503/hortj. MI-081). [CrossRef]

116) Nevala-Puranen N, Kallionpää M, Ojanen K (1996) Physical load and strain in parlor milking. Int J Ind Ergon 18, 277-82 (doi:10.1016/0169-8141(95)00054-2). [CrossRef]

117) Pinzke S, Gustafsson B, Hansson GA (1999) Time consumption and work load in milking of cows. In: XXVIII CIOSTA/CIGR V International Congress on Work Sciences in Sustainable Agriculture, 206-13, Horsens, Denmark.

118) Perkio-Makela M, Hentila H (2005) Physical work strain of dairy farming in loose housing barns. Int J Ind Ergon 35, 57-65 (doi:10.1016/j.ergon.2004.08.004). [CrossRef]

119) Groborz A, Tokarski T, Roman-Liu D (2011) Analysis of postural load during tasks related to milking cows-a case study. Int J Occup Saf Ergon 17, 423-32. [Medline] [CrossRef]

120) Scott GB, Lambe NR (1996) Working practices in a perchery system, using the OVAKO Working posture Analysing System (OWAS). Appl Ergon 27, 281-4 (doi: 10.1016/0003-6870(96)00009-9). [Medline] [CrossRef]

121) Zink KJ (2014) Designing sustainable work systems: the need for a systems approach. Appl Ergon 45, 126-32 (doi:10.1016/j.apergo.2013.03.023). [Medline] [CrossRef]

122) Vayrynen S (1988) Computer as aid to analyze work postures-basic principles and advantages of 2 graphic OWAS 
applications. In: 10th Congress of the International Ergonomics Assoc (Ergonomics International 88), 206-8, Sydney, Australia.

123) Long AF (1992) A computerized system for OWAS field collection and analysis. In: International conf on computer-aided ergonomics and safety 92-(CAES 92), 353-8, Tampere, Finland.

124) Engstrom T, Medbo P (1997) Data collection and analysis of manual work using video recording and personal computer techniques. In: Annual Conference of the NordicErgonomics-Society, 291-8, Stenungsund, Sweden. [CrossRef]

125) Pinzke S, Kopp L (2001) Marker-less systems for tracking working postures--results from two experiments. Appl Ergon 32, 461-71 (doi:10.1016/S0003-6870(01)000230). [Medline] [CrossRef]

126) Santos J, Sarriegi JM, Serrano N, Torres JM (2007) Using ergonomic software in non-repetitive manufacturing processes: A case study. Int J Ind Ergon 37, 267-75 (doi:10.1016/j.ergon.2006.10.022). [CrossRef]

127) Rim YH, Moon JH, Kim GY, Noh SD (2008) Ergonomic and biomechnical analysis of automotive general assembly using XML and digital human models. Int J Automot Technol 9, 719-28 (doi:10.1007/s12239-008-0085-7). [CrossRef]

128) Kajihara Y, Taki S (2008) Virtual reality based digital work procedure. In: 9th International Conference on Industrial Management, 995-1000, Osaka, Japan.

129) Cimino A, Mirabelli G (2008) Modelling, simulation and ergonomic standards as support tools for a workstation design in manufacturing system. In: 20th European Modeling and Simulation Symposium, 788-99, Amantea, Italy.

130) Cimino A, Longo F, Mirabelli G (2009) A multimeasurebased methodology for the ergonomic effective design of manufacturing system workstations. Int J Ind Ergon 39, 447-55 (doi:10.1016/j.ergon.2008.12.004). [CrossRef]

131) Taki S, Kajihara Y, Kadowaki M (2010) Evaluation of digital work design supporting system in consideration of work burden analysis. In: 10th International Conference on Industrial Management, 43-7, Beijing, China.

132) Miura K, Izumi K, Kajihara Y, Taki S (2012) Development of a work posture design system. In: 11th International Conference on Industrial Management (ICIM 2012), 12933, Tokyo, Japan.

133) Liu JF, Chen M (2014) Ergonomics simulation and application in production assembly line. In: 3rd International Conference on Materials and Products Manufacturing Technology (ICMPMT 2013), 1780-3, Guangzhou, China.

134) Keyvani A, Johansson H, Ericsson M, Lamkull D, Örtengren R (2011) Schema for motion capture data management. In: 3rd International Conference on Digital Human Modeling (ICDHM)/14th International Conference on Human-Computer Interaction (HCI), 99-108,
Orlando, Florida. [CrossRef]

135) MATLAB (2016) The MathWorks. https://es.mathworks. com/campaigns/products/ppc/google/matlab-trial-request. html action $=$ changeCountry\&s_eid $=$ ppc_29742641962 $\& q=$ matlab\&s_tid=gn_loc_drop. Accessed May 20, 2016.

136) Klippert J, Gudehus T, Zick J (2012) A software-based method for ergonomic posture assessment in automotive preproduction planning: Concordance and difference in using software and personal observation for assessments. Human factors and ergonomics in manufacturing \& sevice industries 22, 156-75. (doi:10.1002/hfm.20370). [CrossRef]

137) Diego-Mas JA, Alcaide-Marzal J (2014) Using Kinect ${ }^{\mathrm{TM}}$ sensor in observational methods for assessing postures at work. Appl Ergon 45, 976-85 (doi:10.1016/j.apergo. 2013.12.001). [Medline] [CrossRef]

138) Kinect. Natural User Interface for Kinect for Windows 2016. Microsoft Developer Network. http://msdn. microsoft.com/en-us/library/hh855352.aspx. Accessed May 20, 2016.

139) Imai Y, Liang SY, Kajihara Y, Munesawa Y, Eguchi M (2016) A method for assessing work postures using Kinect sensor. In: 13th International Conference on Industrial Management (ICIM 2016), 689-94, Hiroshima, Japan.

140) Moar J, Ramos D, Arezes P (2016) Defining the Angles' Range in Ergonomics Assessment Using 3D Cameras and Surface EMG. In: Advances in Safety Management and Human Factors, 463-72, Florida. [CrossRef]

141) Seo J, Yin KQ, Lee S (2016) Automated postural ergonomic assessment using a computer vision-based posture classification. In: Construction Research Congress, 80918, San Juan, Puerto Rico. [CrossRef]

142) Kivi P, Mattila M (1991) Analysis and improvement of work postures in the building industry: application of the computerised OWAS method. Appl Ergon 22, 43-8 (doi:10.1016/0003-6870(91)90009-7). [Medline] [CrossRef]

143) Mattila M, Karwowski W, Vilkki M (1993) Analysis of working postures in hammering tasks on building construction sites using the computerized OWAS method. Appl Ergon 24, 405-12 (doi:10.1016/0003-6870(93) 90172-6). [Medline] [CrossRef]

144) Louhevaara V (1999) Is the physical work load equal for ageing and young blue-collar workers? Int J Ind Ergon 24, 559-64 (doi:10.1016/S0169-8141(98)00061-4). [CrossRef]

145) Li KW, Lee CL (1999) Postural analysis of four jobs on two building construction sites: An experience of using the OWAS method in Taiwan. J Occup Health 41, 183-90 (doi:10.1539/joh.41.183). [CrossRef]

146) Wakula J, Mayer D, Landau K, Motzko C (2003) Analysis and assessment of work output and physical stresses and strains in workers laying floor coverings. In: Annual Spring Conference of the GfA/17th Annual Conference of 
the International-Society-for-Occupational-Ergonomicsand-Safety (ISOES), 1003-5, Munich, Germany.

147) Saurin TA, Guimarães LBD (2006) Ergonomic assessment of suspended scaffolds. Int J Ind Ergon 36, 229-37 (doi:10.1016/j.ergon.2005.11.006). [CrossRef]

148) Bolonha T, Almeida J, Figueiredo JP, Ferreira A (2012) Ergonomics in construction. In: 8th International Symposium on Occupational Safety and Hygiene (SHO), 72-9, Guimaraes, Portugal.

149) Lee TH, Han CS (2013) Analysis of working postures at a construction site using the OWAS method. Int J Occup Saf Ergon 19, 245-50. [Medline] [CrossRef]

150) Yu M, Sun L, Du J, Wu F (2009) Ergonomics hazards analysis of linemen's power line fixing work in China. Int J Occup Saf Ergon 15, 309-17. [Medline] [CrossRef]

151) Kant I, Notermans JHV, Borm PJA (1990) Observations of working postures in garages using the Ovako Working posture Analysing System (OWAS) and consequent workload reduction recommendations. Ergonomics 33, 209-20 (doi:10.1080/00140139008927111). [Medline] [CrossRef]

152) Wright L, Haslam RA (1998) Control of manual handling risks within a soft drinks distribution centre. In: Annual Conference of the Ergonomics-Society Royal-Agricultural-College, 77-81, Cirencester, England,

153) Wright EJ, Haslam RA (1999) Manual handling risks and controls in a soft drinks distribution centre. Appl Ergon 30, 311-8 (doi:10.1016/S0003-6870(98)00036-2). [Medline] [CrossRef]

154) Hoy J, Mubarak N, Nelson S, de Landas MS, Magnusson M, Okunribido O, Pope M (2005) Whole body vibration and posture as risk factors for low back pain among forklift truck drivers. J Sound Vibrat 284, 933-46 (doi: 10.1016/j.jsv.2004.07.020). [CrossRef]

155) Tamrin SBM, Yokoyama K, Jalaludin J, Aziz NA, Jemoin N, Nordin R, Li Naing A, Abdullah Y, Abdullah M (2007) The Association between risk factors and low back pain among commercial vehicle drivers in peninsular Malaysia: a preliminary result. Ind Health 45, 268-78 (doi:10.2486/ indhealth.45.268). [Medline] [CrossRef]

156) Ravnik D, Otáhal S, Dodic Fikfak M (2008) Using different methods to assess the discomfort during car driving. Coll Antropol 32, 267-76. [Medline]

157) Farias S, Lima JFG, Silva MC, Masculo FS (2010) Ergonomics analysis of the activity of loading truck in Brazilian company of ceramic. In: 6th International Symposium on Occupational Safety and Hygiene (SHO 2010), 216-9, Guimaraes, Portugal.

158) Li KW (2010) Working postures analysis for cashiers in a highway toll station. In: International Conference on Engineering and Business Management, 3144-7, Chengdu,
China.

159) Cattaneo CS, Derudi M, Nano G, Rota R, Copelli S, Torretta V, Raboni M (2014) Manual handling operations in an air shipping company: A comparison between risk evaluation methods. In: 22nd Annual Conference on European Safety and Reliability (ESREL), 1817-25, Amsterdam, Netherlands.

160) Calzavara M, Glock CH, Grosse EH, Persona A, Sgarbossa F (2016) Models for an ergonomic evaluation of order picking from different rack layouts. IFAC-PapersOnLine 49, 1715-20. [CrossRef]

161) Fošnarič S, Planinseč J (2010) Useful measures in the field of time and dimensional rationalisation of manual training lessons. Int J Technol Des Educ 20, 137-49 (doi:10.1007/ s10798-008-9067-3). [CrossRef]

162) Petromilli Nordi Sasso Garcia P, Polli GS, Campos JADB (2013) Working postures of dental students: ergonomic analysis using the Ovako Working Analysis System and rapid upper limb assessment. Med Lav 104, 440-7. [Medline]

163) Apaydin U, Erol E, Kocyigit MF, Elbasan B (2016) Determination of the factors correlated with low back pain in teachers. Turkish Journal of Physiotherapy RehabilitationFizyoterapi Rehabilitasyon 27, 42-7.

164) Bogaert I, De Martelaer K, Beutels M, De Ridder K, Zinzen E (2016) Posture analysis among Flemish secondary school teachers: difference between the use of chalkboards and electronic school boards during classroom teaching. Ergonomics 59, 1487-93 (doi:10.1080/0014013 9.2016.1139751). [Medline] [CrossRef]

165) Carrasco C, Coleman N, Healey S, Lusted M (1995) Packing products for customers: an ergonomics evaluation of three supermarket checkouts. Appl Ergon 26, 101-8 (doi:10.1016/0003-6870(95)00007-Y). [Medline] [CrossRef]

166) Sarkar K, Dev S, Das T, Chakrabarty S, Gangopadhyay S (2016) Examination of postures and frequency of musculoskeletal disorders among manual workers in Calcutta, India. Int J Occup Environ Health 22, 151 - 8 (doi:10.1080 /10773525.2016.1189682). [Medline] [CrossRef]

167) Xu YW, Cheng ASK (2014) An onsite ergonomics assessment for risk of work-related musculoskeletal disorders among cooks in a Chinese restaurant. Work 48, 539-45 (doi:10.3233/WOR-131805). [Medline] [CrossRef]

168) Wang MH, Chen BH, Chiou WK (2016) Redesign the cleaning tools from analysis of working postures at a cleaning job using the task analysis and OWAS methods. In: Advances in Physical Ergonomics and Human Factors, 417-26, Florida. [CrossRef] 